\title{
Güçlendirmenin Özü “Güç”: Sosyal Hizmet Uzmanlarının Işs Yerindeki Güçleri/Güçsüzlükleri ${ }^{1}$
}

\author{
The Core of Empowerment is Power: Strengths/Weaknesses of Social Workers at \\ Work
}

Mehmet KIRLIO $\breve{G} L U^{*}$

\begin{abstract}
$\ddot{O} Z$
Bu çalışmanın amacı sosyal hizmet uzmanlarının iş yerindeki güç/güçsüzlüklerini Miley ve diğerlerinin (2016) sınıflandırmasında olduğu gibi kişisel, kişilerarası ve sosyo-politik olmak üzere üç düzeyde ele almaktır. Bu üç düzeyi daha iyi açıklayabilmek adına düzeyler altında konu başlıklarına yer verilmiştir. İs yerindeki kişisel düzeydeki güçler, mesleği isteyerek seçme, başka bir kuruma geçme isteği, sosyal hizmet mesleğini bırakma isteği, doğrudan sosyal hizmet uygulaması yapma, alan deneyimine uygun çalışma konularını kapsamaktadır. İş yerindeki kişilerarası düzeydeki güçler, meslektaşlarından destek ve öneri alma, kurumdaki tüm meslek elemanlarının ortak bir amaca sahip olması, amir yönlendirmesi, üstler ile yaşanan sorunları çözüme kavuşturma, yönetimin tutumu, yönetim ile ilişkiler konularını kapsamaktadır. İş yerindeki sosyo-politik güçler, kadro durumu, işin yapılma şekli konusunda müracaatçılardan ve üstlerden gelen baskı, çalışma yoğunluğu, görüşme sayısı, vaka sayısı, çalışma ortamı, otonomi, ilerleme imkânı konuları kapsamaktadir.
\end{abstract}

ANAHTAR KELIMELER

Güç, Güçlendirme, Kişisel, Kişilerarası, Sosyo-politik

\begin{abstract}
The aim of this study is to examine the power/weakness of social workers in the workplace at three levels: personal, interpersonal and socio-political as in the classification of Miley et al. (2016). In order to better explain these three levels, topics are included under the levels. The powers at the personal level in the workplace include the willingness to choose the profession, the desire to move to another institution, the desire to quit the social work profession, direct social work practice, work in accordance with the field experience. The powers at the interpersonal level the workplace include getting support and suggestions from colleagues, having a common purpose of all professional staff in the institution, supervisor, solving problems experienced with superiors, the attitude of management, the relations with management. The powers at the socio-political level in the workplace include precarious work, pressure from the applicants and superiors, intensity of work, number of interviews, number of cases, working environment, autonomy, possibility of progress.
\end{abstract}

\section{KEYWORDS}

Power, Empowerment, Personal, Interpersonal, Socio-political.

\begin{tabular}{|c|c|c|}
\hline \multicolumn{2}{|r|}{$\begin{array}{c}\text { Makale Geliş Tarihi / Submission Date } \\
\text { 25.07.2019 }\end{array}$} & $\begin{array}{c}\text { Makale Kabul Tarihi / Date of Acceptance } \\
\text { 31.10.2019 }\end{array}$ \\
\hline Atıf & $\begin{array}{l}\text { Kırlıŏlu, M. (2019). Güçlendirmenin } \\
\text { Selçuk Üniversitesi Sosyal Bilimler Me }\end{array}$ & $\begin{array}{l}\text { met Uzmanlarının İş Yerindeki Güçleri/Güçsüzlükleri. } \\
s i, 22 \text { (2), 646-662. }\end{array}$ \\
\hline
\end{tabular}

\footnotetext{
${ }^{1}$ Bu çalışma Sosyal Hizmet Uzmanlarının Kişisel ve Mesleki Güç Algılarının Bazı Değişkenlere Göre İncelenmesi adlı doktora tezinin bir bölümünden oluşmaktadır.

* Dr. Öğr. Üyesi, Necmettin Erbakan Üniversitesi, Sağlık Bilimleri Fakültesi, Sosyal Hizmet Bölümü, kirlioglumehmet@ gmail.com, ORCID: 00000003-0130-0841
} 


\section{GİRIŞ}

Güçlendirme, demokratikleşme, sosyal rollere değer biçme, düşünümsellik ve eleştirel olabilme, bilinçlendirme, radikal sosyal hizmet, baskı karşıtı uygulama gibi kavramlarla ilişki içerisindedir. Ancak güç konusunun güçlendirmenin kalbinde yer aldığı belirtilmektedir (Adams, 2003). Barker (1995) gücü, bir kişinin bağımsız olarak bir şeyler yapması veya başkalarını etkilemek ve onlar üzerinde kontrol sahibi olma olanağı tanıyan kaynaklara sahip olmak olarak tanımlarken, Thompson (2016) ise gücün kuramsal bir kavram olduğunu ve bu yönüyle farklı kuramsal çerçeveler içinde farklı şekillerde anlaşılabileceğini belirtmektedir. Güç, bireylerin yaşamları üzerindeki kontrolü ele alma (Robert Adams, 2008) ve kontrolü elde etme yetisi olarak (Teater, 2015) tanımlanmaktadır. Güç "olumlu ve tatmin edici bir yaşama, verimli bir sosyal işlev görmeye katku sağlayan herhangi bir tutum, kapasite ya da deneyim olarak tanımlanabilir" (Sheafor ve Horejsi, 2014).

Thompson (2016) gücün yetkinlik yani yapabilme becerisi olarak ele alınabileceğini belirtmektedir. $\mathrm{Bu}$ konuda karizmanın yetkinlik olarak güce örnek olarak verilebileceğini, bazı insanların karizmatik özelliklere sahip olsalar da bu gücü kullanamayacaklarını, bu durumun da gücü uygulamaya koyma kapasitesi olarak değerlendirilebileceğini ifade etmektedir. Yine gücün kurumsallaşmış düşünceler ve uygulamalar olarak değerlendirilebileceğini bu konuda söylemler ve anlam yapılarının "normal"lik ölçütlerini belirlediğini, bunların tekrarlanması durumunda kökleştiğini, böylece kurumsal hale geldiğini ve hegemonya kavramı ile ilişkilendirebileceğini belirtmektedir.

Hasenfeld (1987) sosyal hizmet uygulamasında zorlayıcı güçten normatif güce kadar uzanan çok çeşitli güç kaynaklarının olduğunu belirtmektedir. Ancak bunların sadece üç tanesinin uygun olduğunu vurgulamaktadır. İlk olarak mesleki eğitim, sürekli gelişim ve uzmanlık bilgisi ile edinilen profesyonel güçtür. İkincisi uzmanların kişilerarası becerilerinden, özellikle de empati kurma, güven ve müracaatçı ile ilişki kurma yeteneklerinden doğan referans gücü veya ikna gücüdür. Üçüncüsü uzmanlar belirli kararlar almaya ve eylemleri gerçekleştirmeye yönelik mevzuat ve politikadan gelen yasal güç kaynaklarına sahiptir. Bu güçlerin dışında fiziksel araçlarla sınırlı olmayan sosyal, duygusal, politik veya ekonomik gücün kullanımı ile ilgili zorlayıcı güç; kendilerini daha güçlü veya etkili kılmak için bilgileri saklayan kişiler için kullanan bilgiden gelen güç; başkalarının isteklerine uyduğu zaman kullanılan ödül gücü olarak isimlendirilen güç kaynakları mevcuttur (French ve diğ., 1959; Raven, 1993). Bunlara ek olarak Thompson (2016) gücü bireylerin hedeflerine ulaşma yetenekleri ile ilgili olan yapabilme gücü; eşitsiz güç ilişkilerini tanımlayan gücü bask1 olarak kullanma (Yasal gereklilikler başvurma gibi durumlarda gücü baskı olarak kullanmanın gerekebileceği belirtilmektedir. Ancak bunun son çare olarak düşünülmesi gerektiği ifade edilmektedir); birlikte çalışma ve diğerlerini birlikte çalışmaya cesaretlendirerek daha fazlasına ulaşmaya vurgu yapan işbirliğine dayalı güç; ve tinsellik gibi özden gelen güç olarak yararlandığımız dayanıklılığı ve esnekliği başkalarına yardım ederken de kullanmayı ifade eden özden gelen güç olarak özetlenebileceğini belirtmektedir.

Thompson (2016) insanları güçlü ya da güçsüz olarak iki temel kategoriden birine yerleştirme gibi tanımlamaların gücü, aşırı basitleştirmeye iteceğini belirtmektedir. Diğer bir ifade ile gücün basit bir mesele olmadığı, gücün farklı düzey ve boyutlara sahip olduğu ifade edilmektedir. Thompson (2016) gücü kişisel, kültürel (söylemsel) ve yapısal olmak üzere üç düzeyde ele almaktadır. Benzer şekilde Miley, O'Melia, and DuBois (2016) da gücü kişisel, kişilerarası ve sosyo-politik olmak üzere üç düzeyde ele almaktadırlar. Bu noktada gücün kişisel düzeyinde beceriler (iletişim, girişkenlik), kişisel özellikler (cinsel çekicilik, saygınlık, karizma), rol (yönetici) ve tutumlar (özgüven, kendine inanma) bulunmaktadır (Thompson, 2016). Kişisel düzeyde bireylerin kendisini nasıl algıladığı ve nasıl gördüğünün ön planda olduğu belirtilirken bireylerin yaşamları üzerinde kontrol sahibi olmasına, kendilerini yetkin ve ehil olarak görmelerine dikkat çekilmektedir (Miley ve diğ., 2016). Gücün kültürel (söylemsel) boyutunda mikro ölçekte söylemlerin makro ölçekte ise kültürün bireyleri, grupları ve toplulukları belirli kalıplar içerisinde tutarak yönlendirdiği, mikro ölçekteki söylemlerin bir bakıma gerçekleri inşa ettiği, bunun da çok önemli bir güç uygulaması olduğu, diğer bir ifade ile neyin normal neyin anormal olduğunu tanımlama gücüne sahip olduğu belirtilmektedir (Thompson, 2016). Gücün kişilerarası boyutunda bireyler arasındaki etkileşimsellikten bahsedilmekte, bu etkileşimsellikte bireylerin kendi statüsünü belirlediği, bireylerin karşılaştığı güçlükler karşısındaki sosyal desteğin önemi üzerinde durulmaktadır (Miley ve diğ., 2016). Gücün yapısal boyutunda bir kişinin sınıfı, ırkı, etnik kökeni, cinsiyeti, yaşı, engellilik durumu, cinsel kimliği, dini ve konuşulan dili bir güçsüzlük unsuru olarak önemli bir yer tutmaktadır. Bu nedenle bireyler birçok kaynağa (sağlık ve eğitim hizmeti) erişememekte, bir grubun diğer grup üzerinde üstün olduğunu belirten rkç̧1lık gibi hususlara benzer şekilde hegemonik ilişkilerin varlı̆̆ bireylerin güçlüklerle karşılaşmasına neden olabilmekte ve cam tavan kavramında olduğu gibi kadınların üst yönetim pozisyonlarına gelebilmesinin önüne geçilebilmektedir (Thompson, 2016). Gücün sosyo-politik 
boyutu sömürme, kötüye kullanma, faydalanma, kendi çıkarına kullanma ile ilişkili olup bireyler üzerinde hem sosyal hem de psikolojik olarak egemenlik kurma sürecini tarif etmektedir. Bu noktada bireylerin üretici bir güç olarak topluma katılmaları işe yaramaz, sakıncalı, elverişli gibi tanımlamalar nedeniyle engellenmektedir. Irkçılık, cinsiyetçilik gibi baskı türleri bireylerin işsizlik ve yoksulluk gibi kitlesel adaletsizlikler yaşamasına neden olabilmektedir (Miley ve diğ., 2016).

Güçlendirmenin bireysel düzeyinden ziyade çevresel faktörlerin önemine vurgu yapan kimi çalışmalar özellikle iş yerinde güçlendirme kavramından bahsetmektedir (Dee ve diğ., 2003; Speer ve Peterson, 2000; Spreitzer ve diğ., 1997; Thomas ve Velthouse, 1990; Zimmerman, 1990, 1995). Uygulamalarını bir örgüt içerisinde yürütmekte olan sosyal hizmet uzmanları için de iş yerinde güçlendirme hususu önemli bir kavram olarak karşımıza çıkmaktadır. Hem Thomas veVelthouse (1990) hem de Spreitzer (1995) bireyin işteki rolüne oryantasyonunda dört temel güçlendirme bileşeninden bahsetmişlerdir. Bunlar anlamlandırma, yeterlilik hissi, self determinasyon ve etki yapabilme olarak siralanmaktadır. Thomas and Velthouse (1990) self determinasyon kavramsallaştırması yerine seçim yapabilmeyi tercih etmiştir. Örneğin burada bahsedilen self determinasyon ya da seçim yapabilme bireylerin otonomiye sahip olması ile ilgili bir kavramdır (Black ve Deci, 2000; Niemiec ve Ryan, 2009). Sosyal hizmet uzmanlarının da sosyal hizmet uygulamasında otonomiye sahip olmaları gerekmektedir. Ayrıca örgüt içinde karar alma mekanizmalarında etkin bir rolü veya kararları etkileyebilme gücüne sahip olması sosyal hizmet uzmanlarını güçlendiren unsurlar olarak söylenebilir. Örgüt içinde etkin olmadığını düşünen sosyal hizmet uzmanları işi bırakabileceği gibi başka bir kuruma da geçmek isteyebileceklerdir. Örneğin terfi gibi özendirici hususların, örgütün misyonu ve performans ile ilgili bilgiye erişimin güçlendirmenin öncülleri arasında olduğu belirtilmektedir (Spreitzer, 1995). Buna göre çalışma kapsamında sosyal hizmet uzmanlarının iş yerindeki güç/güçsüzlükleri Miley ve diğerlerinin (2016) sınıflandırmasında olduğu gibi kişisel, kişilerarası ve sosyo-politik olmak üzere üç düzeyde ele alınmıştır.

\section{KİŞISEL DÜZEYDEKİ UNSURLAR}

Sosyal hizmet uzmanlarının iş yerindeki güç/güçsüzlüklerini etkileyen kişisel unsurlar mesleği isteyerek seçme, başka bir kuruma geçme ve işi bırakma düşüncesi, doğrudan sosyal hizmet uygulaması ve alan deneyimine uygun çalıştırılma çerçevesinde ele alınacaktır.

\subsection{Mesleği isteyerek seçme}

Meslek seçiminin kişinin o ana kadar geliştirmiş olduğu ben kavramını tamamlayıcı bir özelliği olduğu vurgulanmaktadır (Super, 1951). Özellikle Holland'ın (1997) belirtmiş olduğu gerçekçi, araştırmacı, sanatçı, sosyal, girişimci, gelenekçi gibi kişilik tipolojilerine uygun meslek seçenlerin mutlu ve başarılı olabilecekleri belirtilmektedir (Kamaşak ve Bulutlar, 2010; Kuzgun, 2006). Ayrıca seçilen mesleğe ilgi duyulmasının kişiyi motive ettiği belirtilmektedir (Jurkiewicz ve diğ., 1998). Buna karşın mesleği rastlantısal veyahut yakınlarının baskısı gibi nedenlerle seçmenin güçsüzleştirici etkisi olduğu üzerinde durulmaktadır (Aktuğ ve diğ., 2006; Aslan ve diğ., 1997; Dolunay, 2002; Mollaoğlu ve diğ., 2010; Say1l ve diğ., 1997). Örneğin Aslan ve diğerleri (1997) tarafindan eczacı, diş hekimi, hekim, hemşire, ebe ve sağlık teknisyenlerinden oluşan 397 kişi ile yapılan araştırmada tercih yapma şansı verilse tekrar aynı mesleği seçeceğini belirtenlerin işlerinden aldıkları doyumun yüksek olduğu, işe bağlı gerginlik puanlarının düşük olduğu, kişisel başarı puanlarının yüksek olduğu, duygusal tükenme ve duyarsızlaşma puanlarının düşük olduğu sonucuna ulaşılmıştır. Benzer olarak Sayıl et al. (1997) tarafından iç hastalıkları servisinde çalışan 109 hemşire ve 56 doktor ile yapılan araştırmada mesleğe isteyerek girenlerin iş doyumu yüksek bulunmuştur ve ek olarak kendi isteği dışında rastlantısal ya da yakınlarının önerisi ile mesleği seçenlerin duygusal tükenme içinde oldukları belirtilmiştir. Ankara ili Keçiören ilçesinde 366 öğretmenle yapılan bir başka araştırmada mesleği isteyerek seçen ve mesleği kendine uygun bulan öğretmenlerin duygusal tükenme ve duyarsızlaşma puanlarının anlamlı bir şekilde düşük olduğu, kişisel başarı puanlarının anlamlı bir şekilde yüksek olduğu bulunmuştur (Dolunay, 2002). Cumhuriyet Üniversitesi Hastanesi'nde ve Sivas İzzettin Keykavus Devlet Hastanesi'nde çalışan 387 hemşire ile yapılan çalışmada ise mesleği isteyerek seçenlerin mesleki ilişkilerinin daha iyi olduğu ve iş doyumlarının yüksek olduğu sonucuna ulaşılmıştır (Mollaoğlu ve diğ., 2010). Akademisyenlerle yapılan araştırmada akademisyenliği isteyerek seçenler diğerlerine göre daha az duygusal tükenme ile daha fazla kişisel başarı yaşamaktadırlar (Ardıç ve Polatcı, 2008). Ülkemiz sosyal hizmet mesleğinin çok tanınmaması nedeniyle mesleği isteyerek seçmenin daha az yaygın olabileceği, bu durumun da kişileri etkileyebileceği söylenebilir.

\subsection{Başka bir kuruma geçme ve işi bırakma düşüncesi}

Çalışanların demografik özellikler, psikolojik unsurlar, devamsızlık kültürü ve işletme kontrol politikası nedeniyle başka bir kuruma geçmeyi veya kurum değiştirmek istedikleri belirtilmektedir (Jex ve Britt, 2014). 
Başka bir kuruma geçme ya da işi bırakma düşüncesi bireyden (emeklilik, ölüm, askerlik, hastalık, eğitim, evlilik, hamilelik ve ikâmet değişikliği) ve kurumdan kaynaklanan (ücret, kariyer ve terfi olanakları, stres, iş ve çalışma koşulları, işyerinde taciz, yönetim anlayışı, etik değerler ve iş olanakları) olmak üzere iki başlıkta ele alınabileceği belirtilmektedir (Kaplanoglu, 2014). Sosyal hizmet uzmanları ise kağıt işlerinin ve iş̧ talebinin, ortalama dosya yükü ve görüşme sayılarının yüksek olması gibi iş yükü başlığı altında belirtilen tüm güçsüzleştirici unsurlar nedeniyle işi bırakabilmekte ya da kariyer değişikliği yapabilmekte oldukları ileri sürülmektedir (Calitz ve diğ., 2014). Sosyal hizmet uzmanlarının başta ücret gibi nedenlerden olmak üzere kurum değiştirmeyi düşünebildikleri, bunun da işteki motivasyonu düşürücü etkisi olduğu belirtilmektedir (Gellis, 2001; Güzel ve Selcik, 2017). Işıkhan'ın (1999) yapmış olduğu araştırmada da alınan ücret ve diğer kazançları yeterli görmemenin önemli bir stres kaynağı olduğu belirtilmektedir. Muğla S1tkı Koçman Üniversitesinde görev yapan 279 idari personelle yapılan araştırmada işini değiştirmek isteyenlerin veya başka bir iş isteyenlerin duygusal tükenme ve duyarsızlaşma puanlarının yüksek olduğu, kişisel başarı puanlarının düşük olduğu belirtilmiştir (Bakan ve Tombak, 2014). Yapılan bir çalışmada akademisyenlerden meslek değiştirme ve kurum değiştirme eğiliminde olanların duygusal tükenme ve duyarsızlaşma düzeyleri daha yüksek çıkmıştır. Diğer yandan işini değiştirmek istemeyenlerin kişisel başarı düzeyi daha yüksektir (Ardıç ve Polatc1, 2008).

\subsection{Doğrudan sosyal hizmet uygulaması}

Sheafor ve Horejsi (2014) doğrudan sosyal hizmet uygulamasının yüz yüze etkileşimin olduğu faaliyetleri (aile danışmanlığı, grup çalışması, vaka yönetimi vb.); dolaylı uygulamanın ise müracaatçılarla yoğun temas içermeyen fakat dolaylı olarak mürcaaatçılara yarar sağlayan faaliyetleri (savunuculuk, yönetim, fon sağlama, program planlama ve değerlendirme vb.) içerdiğini belirtmektedir. Yapılan bir araştırmada sosyal hizmet uzmanlarının büyük bölümünün doğrudan sosyal hizmet uygulamasını içeren faaliyetleri gerçekleştirdiği ve bu durumun da iş doyumuna olumlu katk1 sağladığı belirtilmektedir (Ceylan ve diğ., 2016). Koç (2015) çalışmasına dahil olan sosyal hizmet uzmanlarının \%33'ünün sosyal hizmet alanında çalışmaya dair motivasyonlarının olmadığını ve bunun sosyal hizmet uzmanlarının doğrudan meslekleri ile ilgili birimlerde çalışmamaları ve müracaatçı ile karşılaşmamalarından kaynaklı olduğunu saptamıştır. Örneğin Acar ve diğerlerinin (2017) yapmış olduğu araştırmada uzmanların varoluşu sadece yasaları uygulamaktan ibaret olan bir memur gibi hareket etmesine bağlı olduğu ve bunun da uzmanların mesleki tükenmişlik yaşamasına neden olduğu belirtilmektedir. Bu noktada katılımcılardan biri "Yasal mevzuat mesela engelliler için sosyal yardım sağllyor; onun dışında, sosyal hizmet adına bir şey yok Türkiye'de, olsa da minimal düzeyde belki; çok kurumsallaşmadan, standartlaştırılmadan yapılan işler. Ondan da meslekdaşlarım vakaya gidip, vakanın temel ihtiyaçlarını görüp, gelip kurumsal hizmetlere baktığında, yeterli hizmetin olmaması nedeniyle arada sıkışıyor. Mesleğine olan inancının da bu anlamda zayıfladı̆̆ını görüyorum." ifadesiyle mesleki tükenmişliğini gözler önüne sermektedir. Zengin ve Çalış (2017) çalışmasına dahil olan sosyal hizmet uzmanlarının büyük çoğunluğunun $(\% 89,4)$ müracaatçılarla doğrudan çalışma gerçekleştirdiğini, \%10.6'sının ise müracaatçılarla doğrudan çalışmadığını saptamıştır. Diğer taraftan Özbesler ve İçağasığlu-Çoban (2009) hastane ortamlarında yaptıkları çalışmada sosyal hizmet uzmanlarının aile ve bireyle çalışma, sosyal hizmet yönetimi, grup çalışması gibi doğrudan mesleki çalışmalar yapma sıklığının düşük olduğunu ortaya koymuştur. Sosyal hizmet uzmanlarının gerçekleştirdikleri müdahalelerin müracaatçıları üzerinde faydalı olduğunu görmek ve hissetmek isteyebileceğinden hareketle (Uğur ve Erol, 2015) doğrudan ve dolaylı uygulama oranında doğrudan uygulama oranının yüksek olması güçlendirici unsur olarak değerlendirilebilir. $\mathrm{Bu}$ çerçevede geri bildirim alabilmenin mesleki ve kişisel güç açısından önemli bir etken olduğu görülmektedir.

\subsection{Alan Deneyimine Uygun Çalıştırılma}

Sosyal hizmet uzmanları genelci sosyal hizmet eğitimiyle tüm rol ve işlevlere uygun yetiştirilmesine rağmen uzmanlar yıllarca çalıştıkları alanlarda uzmanlaşmakta olup sosyal hizmet uzmanlarının yetkin ve donanımlı oldukları alanlarda görev yapmaları kendi gelişimleri ve müracaatçıya sağlayacakları yarar açısından son derece önemlidir (William, 1998). Diğer bir ifade ile alan deneyimine uygun çalıştırılma sosyal hizmet uzmanlarını güçlendiren bir husus olarak karşımıza çıkmaktadır. Ancak sosyal hizmet uzmanlarının mesleki rollerinin ve sorumluluklarının dışındaki görevlerde çalıştırılabildikleri ve mesleki deneyimin dikkate alınmadığı (Aydemir, 2003; Berkün, 2010; Işıkhan, 2011; Koç, 2015; Kol, 2009; Merighi ve Ehlebracht, 2005; Özbesler ve İçağasığlu-Çoban, 2009; Sheafor ve Horejsi, 2014; Yağc1, 2017) belirtilmektedir. Sosyal hizmet uzmanları, mesleki müdahalelerde bulunmalarına neden olan engellerin, kalabalık bekleme listeleri ve sosyal hizmetle ilgili olmayan görevlendirmeler başta olmak üzere bir dizi sorundan oluştuğunu belirtmektedirler (Whitaker ve diğ., 2006). Berkün (2010) çalışmasında, sosyal hizmet uzmanlarının bir alanda daha yetkin 
olacak şekilde uzmanlaşmak istediklerini fakat yetersiz meslek elemanı olmasına karşıllık müracaatçı sayısının fazla olması nedeniyle işlemleri yetiştirebilmek için birçok alanla ilgilenmek zorunda olduklarını ortaya koymuştur. $\mathrm{Bu}$ durum mesleki rollerindeki belirsizliğe, rol çatışmalarına, kariyere uygun olmayan görevlendirmelere neden olmakta ve bu da sosyal hizmet uzmanlarında tükenmişliğe neden olmaktadır (Işıkhan, 2011). Benzer şekilde Eğinli (2009) de çalışanların deneyimlerine uygun pozisyonlarda görevlendirilmediklerinde mutsuz oldukları ve iş doyumlarının azaldıklarını belirtmektedir.

\section{KISŞILERARASI DÜZEYDEKİ UNSURLAR}

Sosyal hizmet uzmanlarının iş yerindeki güç/güçsüzlüklerini etkileyen kişilerarası unsurlar meslektaşlarından destek ve öneri alma, tüm meslek elemanlarının ortak bir amaca sahip olması, amir yönlendirmesi, üstler ile yaşanan sorunlar, yönetimin tutumu ve yönetim ile ilişkiler çerçevesinde ele alınacaktır.

\subsection{Meslektaşlarından Destek ve Öneri Alma}

Genel olarak destek ve öneri almanın çalışanların kişisel ve mesleki gelişimlerini desteklediği, mesleki doyumu ve çalışma verimini arttırdığı, kaynakların etkin kullanılmasını sağladığı, vaka yönetimi konusunda yol gösterdiği, olumsuz duyguların üstesinden gelinmesinde yardımcı olduğu, uzmanların plan yapabilme becerisini geliştirdiği belirtilmektedir (Brashears, 1995; Bujdová ve Kmec, 2012; Carpenter ve diğ., 2017; Kadushin ve Harkness, 2014). Destek ve öneri konusunun önemi, yapılan çalışmalarla desteklenmektedir. Rize ilinde bulunan 12 sosyal hizmet uzmanı ile yapılan nitel araştırmada özellikle mesleğin başlangıç yıllarında sosyal hizmet uzmanlarının kendi içlerindeki dayanışma ile birbirlerine destek oldukları, vakalarla ilgili birbirlerine öneri sundukları belirtilmiştir (Güzel ve Selcik, 2017). Aynı araştırmada katılımcılardan biri "Kurumu tanıyarak ve bilerek geldim. Benim için artı bir şey oldu; ama tabi ki işleyiş konusunda her zaman T. Bey, siz de tanıyorsunuz, baya bir deneyimli olduğu için [...] benim açıkçası o anlamda sıkıntıya düştügüum vakalarda hani tecrübeli olan insanlara çalışanlara sorup çözüm aramaya çalıştım” diyerek deneyimli meslektaşlarından aldığı destek ve önerinin önemine dikkat çekmektedir. Özellikle sosyal hizmet uzmanlarının sözel veya fiziksel saldırı ile karşı karşıya kaldıklarında başta meslektaşlarından olmak üzere kurum personelinden destek görmelerinin işteki motivasyonlarını arttırdığı vurgulanmaktadır. Aksi takdirde sosyal hizmet uzmanları yalnızlık, tedirginlik ve kaygı hissedebilmektedirler. Sosyal hizmet uzmanları mesleğe yeni başladıklarında ya da ileri süreçlerde kurum/kuruluşun zorunlulukları ve yerel beklentiler arasında ortaya çıkan gerilimleri giderme ve profesyonelliğe aykırı olarak değerlendirilen mesleki yaşamın bireyselleştirilmesi ile karşı karşıya kaldıklarında (Pugh, 2007) meslektaşların desteği ile bunun üstesinden gelebileceği belirtilmektedir. Aksi takdirde sosyal hizmet uzmanları meslektaşları tarafından kötü bir şekilde motive edilme (Gellis, 2001) ile karşı karşıya kalabilmektedir.

Sosyal hizmet uzmanlarının meslektaşlarından destek ve öneri alamayanların ve ek olarak meslektaşları ile çatışma yaşayanların stresle karşı karşıya kaldıkları ve diğer taraftan destek almanın koryucu bir etkisi olduğu belirtilmektedir (Acar ve diğ., 2017; Işıkhan, 1999; Lloyd ve diğ., 2005). Sosyal hizmet uzmanları arasında formel ya da informel destek mekanizmalarının olmamasının stresi arttıran bir yönü olduğu belirtilmektedir (Cherniss, 1980; Cooper, 1981; Işıkhan, 1999). Bu yüzden sosyal hizmet uzmanlarının stresle başa çıkmalarını güçlendirebilmek için uygun formal ve informal destek sistemlerine ihtiyaç olduğu ifade edilmektedir (Collins, 2007). Ayrıca meslektaşların bir birine destek olmadığı bir çalışma ortamında sosyal hizmet uzmanlarının kendilerini kurumlarından ve meslektaşlarından soyutlanmış hissedebileceği belirtilmektedir (Chandler, 1987).

Formel destek sistemlerinden olan süpervizyon sisteminde supervizörlerden gelen sosyal desteğin duygusal tükenmeyi azalttığı ve kişisel başarıyı arttırdığı belirtilmiştir (Yürür ve Sarıkaya, 2012). Ancak bu sistemde de süpervizör ile bir araya gelmede zorluk yaşandığ 1 , süpervizor tarafından yetersiz destek verildiği ve verimsiz ve yetersiz süpervizyon süreçlerinin yaygın olduğundan bahsedilmektedir (Gellis, 2001). Sosyal hizmet uzmanlarının meslektaşlarından destek alması dışında bu desteğin sistemli bir şekilde sunulması önemli olmakla beraber ülkemizde maalesef böyle bir sistem bulunmamaktadır. Süpervizyonunun sosyal hizmet bölümlerinde lisans ve lisansüstü eğitim veren üniversitelerde öğretim elemanları tarafından verilen bir ders olarak kaldığı, bunun ötesine geçemediği ve bu durumun da sosyal hizmet alanındaki yansımalarının olumsuz olduğu vurgulanmaktadır (Acar ve diğ., 2017).

\subsection{Tüm Meslek Elemanlarının Ortak Bir Amaca Sahip Olması}

Aynı amaç uğruna takımın bir parçası gibi çalışmanın motivasyon sağladığı belirtilmektedir (Jurkiewicz ve diğ., 1998). Gellis (2001) sosyal hizmet uzmanlarının, çalışma arkadaşlarının kendi işlerini yapmamasından 
şikayet ettiklerini, her uzmanın aynı hassasiyetle müracaatçıya dönük çalışmalarını gerçekleştirmediğini belirtmektedir. Ek olarak çalışma arkadaşları tarafından ortak amaca uymayacak şekilde olumsuz bir şekilde motive edildiklerini yönünde ifadeleri olduğunu dile getirmektedir. Örneğin sosyal hizmet uzmanı kendi alanından olmayan bir yönetici ile çalışmak durumunda kaldığında, ciddî sorunlar yaşayabildikleri, aynı dili konuşamadıkları, bunun da müracaatçıların ihtiyaçlarının giderilmesi konusunda sorun yarattığı, aynı dili konuşamadıklarında sosyal hizmet uzmanının müracaatçılar ile ilgilenmek yerine neden böyle yaptığını, kendini ve mesleğini anlatmak zorunda kaldığı, bu durumun da uzmanlarda tükenmişliğe ve yılgınlığa yol açabildiği belirtilmektedir (Acar ve diğ., 2017). Bu nedenlerden hem yöneticilerin hem de çalışanların ortak bir amaca sahip olması gerekmektedir. Ayrıca Frans (1993) sosyal hizmet uzmanlarının kişisel ve mesleki güçlerini değerlendirirken kurumdaki tüm çalışanların ortak bir amaca sahip olması değişkeninin de hesaba katılmasını belirtmektedir. Hatta bu ifadeye geçerlilik ve güvenirliğini yapmış olduğu kişisel ve mesleki güç algıları ölçeğinin "kolektif kimlik" alt boyutu altında yer vermiştir. Belirtilen ölçeğin Türkçe geçerlilik ve güvenirliği Kırlığlu ve Karakuş (2019) tarafından yapılmış olup ölçeğin yapı geçerliliğinde yapılan doğrulayıcı faktör analizi çalışmasına katılan 401 sosyal hizmet uzmanının \%24,2'si kurumundaki tüm çalışanların ortak bir amaca sahip olmadığını, \%35,4'ü ise kurumundaki tüm çalışanların ortak bir amaca sahip olup olmadığı konusunda emin olmadıklarını belirtmiş̧lerdir.

\subsection{Amir Yönlendirmesi}

Amir yönlendirmesinin meslekî değerlerin yaşama geçirilmesi gibi birçok noktada tıknanan sosyal hizmet uzmanlarının önünü açabileceği, özellikle de mesleğe yeni başlayan sosyal hizmet uzmanlarının hangi durumda ne yapacaklarını ve duruma ilişkin ne tür bir yol izleyeceklerinin amir yönlendirmesi ile mümkün olabileceği, uzmanların mesleki deneyimi arttırabileceği, müracaatçlların beklentilerine uygun hizmetin geliştirilmesinde önemli olduğu belirtilmektedir (Acar ve diğ., 2017; Güzel ve Selcik, 2017; Storey ve Billingham, 2001). Yapılan bir araştırmada katılımcılardan biri "Genelde şey yapıyoruz işte müdürümüze danışıyoruz, müdür yardımcımıza danışıyoruz" diyerek amir yönlendirmesinin önemine dikkat çekmektedir (Güzel ve Selcik, 2017). Güney Galler'de sosyal hizmetler departmanında çalışan sosyal hizmet uzmanları ile yapılan bir araştırmada uzmanların yöneticilerin yönlendirmesi ve desteğinin olmamasından şikâyet ettikleri ve bu durumun da kendileri için bir stres kaynağı olduğu belirtilmektedir (Storey ve Billingham, 2001). Sosyal hizmet uzmanlarının iş streslerinin azaltılarak mesleki tatminlerinin sağlanması için çalıştıkları kurum ve kuruluş amirleri tarafından iş koşullarının, uzmanların mesleki ihtiyaçlarını karşılayacak şekilde düzenlenmesinin önemli olduğu belirtilmektedir (Zengin ve Çalış, 2017).

Literatürde Cherniss (1980) amir yönlendirmesinin bürokratik işlemlerden öteye geçmemesini eleştirmektedir. Collins (2007) destek sistemlerinin sosyal hizmette iki kategoride ele alındığını, bunların yönetim kademeleri, değerlendirme sistemleri ve süpervizyonu içeren formal destek sistemleri; sosyal hizmet ortamlarının içinden ya da dışından gelen desteği içeren informal destek sistemleri olduğunu belirtmektedir. Özellikle bu noktada formal destek sistemlerinin sosyal hizmet uzmanları için önemli bir destek kaynağ olduğu belirtilmekte ve bu kaynağın harekete geçmesinde ve işlevsellik kazanmasında amirlerin yönlendirmesinin önemi vurgulanmaktadır (Collings ve Murray, 1996). Uğur ve Erol (2015) da benzer olarak yöneticilerin kendileri dahil olmak üzere süpervizör ve sosyal hizmet uzmanlarını içeren bir sosyal destek sisteminin oluşturması yönündeki çabaların üzerinde durmaktadır.

\section{4.Üstler ile Yaşanan Sorunlar}

Üstlerin alana uzak meslek elemanlarından olmaları, gerekli ya da uygun bakış açısıyla yaklaşamamaları, uzmanların sistematik biçimde uygulanan kötü muamele ile karşı karşıya kaldıkları ve yaptıkları iyi uygulamalar karşısında takdir edilmedikleri nedenleri ile üstlerle soyun yaşanabildiği (Abu-Bader, 2000; Ceylan ve diğ., 2016; Çetin ve diğ., 2015; Gellis, 2001; Koç, 2015) belirtilmektedir. Sosyal hizmet uzmanları iş yerlerindeki mesleki destek ve ilginin yok olmasından, yönetim ile bölünmelerin şiddetlenmesinden şikâyet etmektedirler ve bu durumun da üstler ile yaşanan sorunları arttırdı ğı belirtilmektedir (Jones, 2001). Örneğin eğitim alanında yapılan bir çalışmada üstlerden takdir görmeyenlerin duygusal tükenme ve duyarsızlaşma puanlarının anlamlı bir şekilde yüksek olduğu, kişisel başarı puanlarının anlamlı bir şekilde düşük olduğu bulunmuştur (Dolunay, 2002).

\subsection{Yönetimin Tutumu}

Türkiye'de sosyal hizmet uygulamalarının yönetimin tutum ve anlayışına göre belirlendiği ve sosyal hizmet mesleğinin personel ve yöneticiler tarafından yeterince tanınmadığı ifade edilmektedir (Özbesler ve İçağasıŏglu-Çoban, 2009). Ayrıca sosyal hizmet uzmanlarının yaptı̆̆ işin mahiyeti yöneticiler tarafından tam 
olarak kavranamaması (İçağasığlu-Çoban ve Özbesler, 2016) da yönetimin tutumunu etkilemektedir. Acar ve diğlerleri (2017) tarafından yapılan çalışmada katılımcılardan biri "Kurumda meslekî çalışmalarımızın miadı 10 yıl. Arkadaşlarımız, bu 10 yıl içerisinde bulunan arkadaşlarımız da hep, kendilerini var etmeye çalışıyorlar sisteme karşı. Sistem hala bizi içine almış ve benimsemiş değil." ifadesiyle Türkiye'de sosyal hizmetin içinde bulunduğu durumu özetlemektedir. Ceylan ve diğerleri (2016) tarafından farklı kurum ve alanlarda çalışan 192 sosyal hizmet uzmanı ile yapılan araştırmada idarecilerin çoğunluğunun sosyal hizmet alanlarına, yöntem ve tekniklerine yabancı olduğu, sosyal hizmet alanlarında görev yapan idarecilerin sosyal hizmet uzmanlarını yönetme ve yönlendirme konusundaki yetersiz oldukları ve sosyal hizmet uzmanlarını nasıl çalıştıracaklarını bilmedikleri ortaya koyulmuştur. Buna ek olarak sosyal hizmet uzmanlarının amirlerinin sadece \%25'inin kendi mesleklerinden olduğu, \%25'inin ise imam, işletmeci, iktisatçı ve gazeteci gibi mesleklerden oluştuğu bulunmuştur. Bunların yanında sosyal hizmet uzmanlarının, yöneticileri ile meslektaş olmamaları ve yöneticilerin alana uzak olmalarından negatif yönde etkilendikleri ve bu etkinin motivasyon ile anlamlı farklılık oluşturduğu tespit edilmiştir (Çetin ve diğ., 2015). Benzer olarak "çalıştı̆̆ kurumda idarenin mesleğine ilişsin düşünce ve tavırları" ile çalıştığı kurumdaki amirinin mesleği arasında anlamlı ilişki bulunmuştur. Sosyal hizmet uzmanları üzerinde en yüksek olumlu etki düzeyine sahip amirin mesleği \%70 ile "sosyal hizmet uzmanı" iken en yüksek olumsuz etki düzeyine sahip amirin mesleği \% 43 ile "öğretmen" olarak görülmektedir (Ceylan ve diğ., 2016). Ayrıca sosyal hizmet kurumlarında yapılan işleri önemsememesi ve gerçekleştirilen iyi işlerin onaylanmaması ve takdir edilmemesi yönündeki yönetim tutumlarının çalışanları olumsuz etkilediği belirtilmektedir (Gellis, 2001; Işıkhan, 1999).

\subsection{Yönetim İle İlişskiler}

Sosyal hizmet alanında çalışanların yönetim ile yaşadıkları sürtüşme ve sorunların çalışanların iş motivasyonunu etkilediği, yönetimle farklı görüşlerde olma ve yönetimsel uygulamaları eleştirememenin yönetim ile ilişkilerde strese neden olduğu vurgulanmaktadır (Gellis, 2001; Işıkhan, 1999). Ayrıca yönetim ile kurulan ilişkinin boyutu ile yönetim ve kuruma duyulan güven arasında anlamlı ilişkiler olduğunu ortaya koyan çalışmalar bulunmaktadır (Özarallı ve Torun, 2011; Uz, 2006; Yalçınkaya, 2007). Örneğin çeşitli kamu kuruluşlarında görev yapan 262 memur ile yapılan araştırmada memurların yönetim ile ilişkileri ve güven arasında pozitif bir ilişki olduğu ortaya koyulmuştur (Uz, 2006). Yalçınkaya (2007) Kütahya'da faaliyet gösteren en büyük üç şirketin çalışanları ile yaptığı araştırmasında çalışanların yönetim ile ilişkilerinin iyi olmasının yönetime olan güveni arttırmanın yanında kurum içerisinde çalışanların yaratıcılıklarının ortaya çıkmasına da anlamlı katkı yaptığ ile yapılan farklı bir çalışmada biçimsel iletişim kanallarının açık ve verimli çalışması sağlanarak çalışanlar ile yönetim arasında oluşturulan iyi ilişkilerin güven ortamını sağladığı ifade edilmektedir (Özarallı ve Torun, 2011).

\section{SOSYO-POLITIKK DÜZEYDEKİ UNSURLAR}

Sosyal hizmet uzmanlarının iş yerindeki güç/güçsüzlüklerini etkileyen sosyo-politik unsurlar güvencesizlik, işi yapılma şekli konusunda müracaatçılardan ve üstlerden gelen baskı, çalışma yoğunluğu, görüşme sayısı, vaka sayısı, çalışma ortamı, otonomi ve terfi imkanı çerçevesinde ele alınacaktır.

\subsection{Güvencesizlik}

Çalışma, toplum içerisinde gerçekleştirilen çekirdek eylemlerden biri olarak gösterilmektedir. Ayrıca çalışmanın bireysel kimliğin merkezi olduğu, bireyleri birbirine bağladığı ve sınıf sistemi içinde insanları yerleştirdiği belirtilmektedir (Kalleberg, 2009). Güvenceli bir işin, istikrarlı ve güvenli bir gelecek sunmasının iş yaşamındaki motivasyonel etmenlerden biri olduğu ifade edilmektedir (Jurkiewicz ve diğ., 1998). Bununla bağlantılı olarak çalışma yaşamında çalışanların güvenceli çalışması diğer bir ifade ile kadrolu işlerinin olmasının çalışanların belirsizlikten kaynaklı düşüncelerden uzak kalarak zihinsel sağlıklarını koruduğu, çalışma yaşamındaki stresi azalttığı, güvenceli çalışmanın çalışanların iş yapma becerisini geliştirdiğgi, mesleki ilişkilerini güçlendirdiği, çalışanların yaptığ iş̧ten gurur duymasını sağladığı gibi bir dizi önemli hususlar vurgulanmaktadır (Benach ve Muntaner, 2007; Clarke ve diğ., 2007; Kim ve diğ., 2008; Kim ve diğ., 2008; Lewchuk ve diğ., 2003; Menéndez ve diğ., 2007; Min ve diğ., 2016; Siefert ve diğ., 1991).

Güvencesiz çalışma koşullarının esneklik, etkinlik ve modernizasyona yönelik itici güçlerin bir sonucu olduğu (Jones, 2001; Spolander ve diğ., 2014) sosyal hizmetin güvencesiz çalışma koşullarından olumsuz bir şekilde etkilendiği ve bu durumun da müracaatçılar ve sosyal hizmet uzmanları için olumsuz sonuçları olduğu vurgulanmaktadır (Min ve diğ., 2016; Özcan ve diğ., 2017; Seifert ve diğ., 2007; Spolander ve diğ., 2014). 
Örneğin ülkemizde Özcan ve diğerleri (2017) tarafından güvencesiz çalışan 14 sosyal hizmet uzmanı ile gerçekleştirilen araştırma sonucunda güvencesiz çalışan sosyal hizmet uzmanlarının bireysel düzlemde kendilerini belirsizlik içinde hissettiği, toplumsal düzlemde ise müracaatçı yararına çalışmadan uzaklaştıkları, güvencesiz çalışmanın etkilerinin bireysel düzlemin ötesinde toplumsal boyuta taşınarak bireylerin hizmet alma ihtiyaçlarının önüne geçtiği tespit edilmiştir. Güvencesiz çalışıldığında bireyler işlerini kaybetme korkusuyla mesai saatleri dışında da çalışmayı kabul etmekte, bu durumu kabullenmediklerinde ise işini kaybedeceğini ya da iş yerinde baskı ile karşılaşacağını düşünmektedirler. Uzmanlar iş yerlerinde işverenin o anki ihtiyacına uygun olarak görevlendirilebilmektedir. Bu çerçevede verilen işlerin kendi mesleğine uygun olup olmadığının önemi olmamaktadır. Uzmanlar ise bu duruma itiraz edememektedirler. Yapılan araştırmada katılımcılardan birinin ifadesi durumu özetler niteliktedir: "Bu kadroda çalışmanın dezavantajları çok fazla. Bunlardan bir tanesi, joker eleman olarak gözükmek. Yani nerede meslek dişı bir iş olsa, sosyal hizmet uzmanının yapmayacağı, yapamayacağı bir iş olsa oraya gönderilmek. Bu, karton taşımak olabiliyor, duvara resim asmak, çivi çakmak, araba ayarlamak, basın-yayının yapması gereken işleri yapmak olabiliyor; yani diğer bütün farkl görev ve sorumlulukları sizin üzerinize yükleyebiliyorlar. Ama ben kadrolu olmuş olsaydım fark tabii ki de olurdu; "Hayır, bu benim işim değil, beni koruyan bir yasam var, 657 sayıl Devlet Memurları Kanununa tabiyim" derdim ve o zaman yapmazdım. Ama şu anda. "Hayır kardeşim, ben bunu yapmıyorum, benim işim bu değil" diyemiyorum, mecburen yapıyorum. Böyle olunca da verdiğim hizmetin kalitesi ve sinıfi değişmiş oluyor". Güvencesiz çalışmanın sosyal hizmet uzmanı ve müracaatçılar arasındaki uzun vadeli ilişkilerini içeren üç sosyal hizmet alanına (yetişkin eğitimi, özel eğitim ve kadın konukevi) ilişkin yapılan başka bir araştırmada ise güvencesiz çalışmanın, sadece istihdam biçiminden dolayı değil aynı zamanda uzmanın işini yapma becerisi ve yaptığı işten gurur duyma becerisi üzerinde de olumsuz bir etkiye sahip olduğu ve bu yolla uzmanın zihinsel sağlık durumunu da etkileyebildiği; ayrıca, başarılı ve üretken çalışmanın dayandığı kişiler arası ilişkilerin zayıflamasına da neden olabildiği belirtilmektedir (Seifert ve diğ., 2007). Taşeron olarak çalışan 19 sosyal hizmet uzmanı ile yapılan nitel araştırmada sosyal hizmet uzmanlarının mecbur kaldıkları için taşeron çalıştıkları ve mümkün olsa kadroya geçmek istedikleri, kadrolu sosyal hizmet uzmanlarına göre çalışma saatlerinin daha fazla olduğu, kadrolu sosyal hizmet uzmanları arasında maaş farkı olduğu, iş kaybı korkusu yaşadığı, kadrolu sosyal hizmet uzmanlarına göre iş yükünün daha fazla olduğu, yasal izin haklarını kullanımları ile ilgili kadrolu sosyal hizmet uzmanlarına göre daha kısıtlı oldukları, İş Kanun' daki hakları konusunda yeteri kadar bilgiye sahip olmadıkları, sendikal faaliyetler konusunda yeterince bilgilendirilmediklerinden dolayı bu faaliyetlere katılamadığı belirlenmiştir (Kalaycı-Kırlığlu ve diğ., 2017). Benzer olarak 2008 Kore Halk Sağlığı Araştırması verileri kullanılarak 51.322 katılımcı (40.514 kadrolu işçi ve 10.808 güvencesiz işçi) ile yapılan bir araştırmada güvencesiz işçilerin kadrolu işçilere göre hastanelere ve dişhekimlerine erişim ile ilgili risk altında olduğu; güvencesiz işçiler arasında doktor kontrollerindeki farklılıkların çoğunlukla yeterli paraya sahip olmamayla bağlantılı olduğu, güvencesiz çalışanlar arasında çekap ve kanser taramaları gibi önleyici ve koruyucu tıbbi hizmetleri alamama riskinin anlamlı bir şekilde yüksek olduğu bulunmuştur (Min ve dĭg., 2016).

\subsection{Müracaatçılardan ve Üstlerden Gelen Baskı}

Bask1, "hak ve özgürlükleri klsitlayarak zor altında bulundurma durumu, tahakküm" (TDK, 2018) olarak tanımlanmaktadır. Kurum/kuruluşlardaki siyasi baskılar gibi nedenlerden dolayı sosyal hizmet uzmanı hizmet alan kişi ile ilgili verdiği karar neticesinde müracaatçının maddi-manevi zarar görmesine yol açarak etik ihlale yol açabilmektedir (Acar ve diğ., 2017). Sosyal hizmet uzmanlarının klasik memur tanımlamasının ötesindeki rol ve sorumluluğunu (Acar ve diğ., 2017; Barker, 1995; Dominelli, 2017; Staudt, 1985) yerine getirmeye çalışıı̆ında da baskı ile karşılaş̧ı̆̆ı söylenebilir. Sosyal hizmet uzmanlarının müracaatçılardan ve üstlerden gelen baskılardan dolayı mesleki değerler ve yönetimsel değerler arasında kalabildikleri belirtilmektedir. Örneğin yapılan bir araştırmadaki katılımcılardan biri basına yansımasın diye tepeden inme kararlar verebildiklerini ya da bir başka katılımcının ifade ettiği gibi müracaatçıların tanıdığının baskısı ile sosyal inceleme raporunun farklı şekilde yazılarak karar değiştirilebildiği ifade etmektedirler (Güzel ve Selcik, 2017). Yine başka bir çalışmada kurum idarecilerinin sosyal hizmet uzmanlarından kendi seçtikleri kişilere sosyal yardım bağlanmasını ya da kendi istedikleri kişilerin kurumlara alınmasını talep ettikleri, uzmanların bu konudaki meslekî bilgi ve donanımlarını hiçe saydıkları, bu durumun sosyal hizmet uzmanlarının kendilerini baskı altında hissetmelerine neden olduğu, müracaatç1ların durumlarına uygun olmayan hizmetlerin sunulmasına yol açtığı ve müracaatçılar arasında hizmete erişimde eşitlik ve tarafsızlık ilkesinin bozulmasına yol açtığı belirtilmektedir. Böylece baskı nedeniyle uzmanın verdiği karar müracaatçılar ile ilgili değer harcamasına neden olabilmektedir (Acar ve diğ., 2017). Başka bir araştırmada siyasal nitelikteki bask1 ve müdahalelerin çalışanların çalışma disiplinini etkilediği belirtilmektedir (Işıkhan, 1999). Ayrıca yöneticiler 
tarafindan sosyal hizmet uzmanlarının maksimum sayıda vaka almasına yönelik büyük bir baskı olduğu belirtilmektedir (Jones, 2001).

\section{3.İş Yükü (Çalışma Yoğunluğu, Görüşme Sayısı ve Vaka Sayısı)}

Sosyal hizmet uzmanlarının mesleki olarak sorumluluklarını yerine getirerek etkili müdahaleler tasarlayabilmesi ve etkili müdahaleler için her müracaatçıya yeterli zaman ayırabilmesinin yolunun ara elemanlar yolu ile sağlanabileceği belirtilmektedir. Ara elemanların yardımı ile sosyal hizmet uzmanlarını mesleki çalışmadan alı koyan etmenlerin (sekretarya işleri vb.) de ortadan kaldırılacağı ifade edilmektedir (Tomanbay, 2011). Çünkü bu tarz işler sosyal hizmet uzmanlarının vakitlerini çok fazla almaktadır ve yapmaları gereken asıl işleri engellemektedir. Sosyal hizmet uzmanı başına düşen görüşme ve vaka sayısının, müracaatçıların bütüncül değerlendirmesini veya tüm yönlerini içerecek şekilde yapılabilmesine olanak sağlaması ve vaka takibine izin vermesi gerektiği vurgulanmaktadır (Acar ve diğ., 2017; Dominelli, 2010, 2015). Ancak esneklik, etkinlik ve modernizasyona yönelik itici güçlerin bir sonucu olarak (Jones, 2001; Spolander ve diğ., 2014) hizmetlerin niteliğinden ziyade niceliğini ortaya çıkaran bir anlayışın hüküm sürdüğü günümüzde sosyal hizmet uzmanlarının nitelikli uygulamalar yapmasının önünde engel teşkil ettiği söylenmektedir (Acar ve diğ., 2017; Dominelli, 2010, 2015). Literatürde yapılan çalışmalarda sosyal hizmet uzmanlarının yoğun iş yükü altında ezildikleri, çalışma yoğunluğunun diğer meslek elemanlarına göre fazla olduğu, sosyal hizmetin bürokratikleştirilmesinden kaynaklı kâğıt işlerinin ve iş talebinin çok olduğu, ortalama dosya yükü ve görüşme sayılarının yüksek olduğu, bu durumun iş doyumlarını düşürdügü̈, tükenmişliklerini arttırdığı belirtilmektedir (Amir ve Kihoro, 2014; Arches, 1991; Balanuye, 2014; Basım ve Şeşen, 2005; BenZur ve Michael, 2007; Berkün, 2010; Blomberg ve diğ., 2014; Butler, 1990; Calitz ve diğ., 2014; Ceylan ve diğ., 2016; Chandler, 1987; Coffey ve diğ., 2004; Collings ve Murray, 1996; Gellis, 2001; Güzel ve Selcik, 2017; Hablemitoğlu ve Özmete, 2012; Iş1khan, 1999, 2010; Johnson ve diğ., 2005; Jones, 2001; Kalliath ve Kalliath, 2013; Karacaoğlu ve Çetin, 2015; Kim ve Stoner, 2008; Lloyd ve di ̆., 2002; Lloyd ve diğ., 2005; Parry-Jones ve diğ., 1998; Powellve diğ., 2013; Robinson, 2013; Storey ve Billingham, 2001; Yürür ve Sarıkaya, 2012). Merighi ve Ehlebracht (2005) çalışmalarında, eğitim süreçlerinde herhangi bir yeri olmamasına ve meslekleriyle doğrudan ilişkili olmamasına rağmen sosyal hizmet uzmanlarının çoğunun sekretarya işleri ile, müracaatçıların ulaşım, konaklama gibi giderlerini karşılamakla uğraştıklarını belirtmişlerdir. Bu çalışmanın sonucunda, meslek dışı sorumluluklar almak zorunda kalan sosyal hizmet uzmanlarının iş doyumlarının düşük olduğu ve duygusal açıdan iyi olmadıkları ortaya konmuştur. Kurum, kuruluş amirine vekalet, toplantılarda ya da faaliyetlerde kurum temsili, kurum içi personel toplantıları, özel günlerde yapılacak kutlama ve etkinlikler için hazırlıklar gibi faaliyetler mesleki çalışmaların yapılmasına engel olmaktadır (Berkün, 2010; Sheafor ve Horejsi, 2014; Yağc1, 2017). Ayrıca iş yükü nedeniyle önemli derecede stres altındaki sosyal hizmet uzmanlarının müracaatçıları adına iyi bir değerlendirme yapamayacakları belirtilmektedir (Pugh, 2007).

\section{4.Çalışma Ortamı}

Çalışma ortamının etik sosyal hizmet uygulamasına elverişli olması, çalışma ortamında örgütsel ve sosyal hizmet uygulama hedefleri arasında uyumun olması, hizmet kullanıcılarının çıkarlarının korunduğu ve iyi uygulama standartları ve kaliteli hizmetlerin tesisinin sağlandığı gibi bir dizi hususları barındırması gerektiği belirtilmektedir (AASW, 2010; IFSW, 2012). Sosyal hizmetin süreç odaklı bir meslek olması çalışma ortamından etkilenmesinin en önemli nedeni olarak sunulmaktadır (Acar ve diğ., 2017). Hatta çalışma ortamının etik ihlâl ve sorunları engelleyebilen bir yönünün olduğu vurgulanmaktadır. Örneğin mahremiyeti ve gizliliği garanti altında alan bir görüşme odasının olmasının önemi üzerinde durulmaktadır (Kadushin ve Kadushin, 2016). Çalışma ortamının sosyal hizmet uzmanlarını, kendini geliştirmesine olanak tanıması, duygusal destek sağlaması, çalışma ilkeleri açısından etkilediği ifade edilmektedir (AASW, 2010; IFSW, 2012; Jones ve Truell, 2012; Wagner ve diğ., 2001). Ayrıca çalışma ortamının kişiyi motive edici bir özelliği olduğu belirtilmektedir (Jurkiewicz ve diğ., 1998)

Sosyal hizmet uygulamasında çalışma ortamının etik uygulamayı destekleyecek şekilde düzenlenmesi gerektiği (Jones ve Truell, 2012) vurgulanmasına rağmen sosyal hizmet kuruluşlarının fiziki şartlarının ve çalışma ortamlarının elverişsiz olduğu vurgusu birçok çalışmada yapılmaktadır (Chandler, 1987; Cherniss, 1980; Cooper, 1981; Gellis, 2001; Güzel ve Selcik, 2017; Hablemitoğlu ve Özmete, 2012; Iş1khan, 1999; Lloyd ve King, 2004; Lloyd ve di ̌̆., 2002; Lloyd ve diğ., 2005; Storey ve Billingham, 2001). Örneğin Güzel ve Selcik (2017) yaptıkları araştırmada 9 sosyal hizmet uzmanının ve farklı birimlerin bir odada olacak şekilde hizmet vermeye çalıştı̆̆ı, gün içinde çalışma disiplinini bozan birçok faktörün olması nedeniyle sosyal inceleme raporlarını tamamlayamadıkları, görüşme odasının olmaması ya da görüşme odasının farklı amaçlar için

Selçuk Üniversitesi Sosyal Bilimler Meslek Yüksekokulu Dergisi, Yıl: 2019 Cilt: 22 Sayı:2 
kullanılmasından dolayı müracaatçı görüşmelerinin bölünmesi, nöbet odasının uygunsuzluğu, 9 sosyal hizmet uzmanının aynı odada olmasından dolayı herkesin aynı işi yapıyormuş gibi bir algı oluştuğu, bunun da müracaatçıların aldıkları hizmet kalitesini ve sosyal hizmet uzmanlarının kişisel gelişimlerini olumsuz yönde etkilediği belirtilmektedir. Gellis (2001) de benzer olarak sosyal hizmet kuruluşlarında yetersiz ve verimsiz araç-gereçlerin olduğunu, sık sık yarıda kesilmenin yaşanabildiğini, çalışma alanının gürültülü olduğunu, çalışma ortamlarında kişisel zamana yeteri kadar vakit ayrılamadığını vurgulamaktadır. Sosyal hizmet uzmanları bir konu hakkında bilgi sahibi olabilmek için kuruluşlarının yeterli bilimsel ve mesleki donanıma sahip olmadığından şikayet edebilmektedirler. Özellikle kurumlardaki bilgisayarların filtreli olması kimi konulardaki aramaları engelleyebildiği vurgulanmaktadır (Güzel ve Selcik, 2017). Çalışma ortamlarında gerekli kaynaklardan yoksunluk (Chandler, 1987; Hablemitoğlu ve Özmete, 2012; Lloyd ve diğ., 2005) ve işyerinde yeterince gizlilik ve mahremiyetin olmamasının (Hablemitoğlu ve Özmete, 2012) çokça vurgulanan konular arasında olduğu görülmektedir. Çalışma ortamının önemi yapılan çalışmalarda ortaya çıkmaktadır. Örneğin çalışma ortamlarında mesleki yönden kendini geliştirme olanaklarının yaratılmasının sosyal hizmet uzmanlarının stresle baş etmesine kolaylık sağladığı belirtilmektedir (Cherniss, 1980; Cooper, 1981; Işıkhan, 1999). Eğitim alanında yapılan başka bir araştırmada çalışma ortamından memnun olan öğretmenlerin duygusal tükenme ve duyarsızlaşma puanlarının anlamlı bir şekilde düşük olduğu, kişisel başarı puanlarının anlamlı bir şekilde yüksek olduğu bulunmuştur (Dolunay, 2002).

\subsection{Otonomi}

Literatürde otonomi iş eylemleri üzerinde kontrol, bağımsız hareket edebilme/bağımsız karar verebilme, karar alma özgürlüğü (Lawler ve Hage, 1973; McCloskey, 1990) olarak tanımlanmaktadır. Sosyal hizmet uzmanları aldığı eğitim, sahip olduğu etik ilkeler ve yerine getirmesi gereken rol ve işlevleri nedeniyle belirli bir otonomiye sahip olması gerektiği üzerinde durulmaktadır (Lymbery, 1998; Munson, 1996). Hatta otonomi olmadan sosyal hizmet uzmanlarının güçlendirme çalışmalarına katılamayacağı söylenmektedir (Dominelli, 2002, 2017). Özellikle çalışanların önemli kararlar konusunda etkin rol alacak otonomiye sahip olmasının motivasyonu olumlu bir şekilde etkilediği belirtilmektedir (Jurkiewicz ve diğ., 1998)

Spolander ve diğerleri (2014) neoliberalizm ve sosyal hizmet ile ilgili yapmış oldukları araştırmada sosyal hizmetin müracaatçılara yönelik bütüncül değerlendirme perspektifinin kaybedildiği, ekolojik ve güçlendirme yaklaşımının aksine yapısal eşitsizlikler ile kurulan bağdan uzaklaşıldığı sonucuna ulaşmışlardır. Spolander ve diğerlerinin (2014) araştırması Dominelli’nin bahsettiği konu ile örtüşmektedir. Dominelli sosyal hizmet uzmanlarının neoliberalizm karşısında otonomilerini kaybettiğini, sosyal hizmet mesleğinin standart formları doldurmaktan ibaretmiş gibi algılandığını, oysa bundan çok daha fazlasını barındırdığını ve sosyal hizmet uzmanlarının bütüncül değerlendirmesini her daim yapması gerektiğini belirtmektedir (Dominelli, 2010, 2015). Hâlbuki Thompson (2013) sosyal hizmetin gerçekleştirilebilmesi için üzerinde düşünülmesi, zaman harcanması gerektiği, mekanik bir şekilde yapılamayacağı üzerine durmaktadır. Bireylerin biricikliğinden hareketle bireyselleştirilmiş ve ihtiyaca odaklanan hizmet sunumunun (Acar ve diğ., 2017) ancak otonomi ile mümkün olabileceği söylenebilir.

Sosyal hizmet uzmanlarının iş yerinde sahip olduğu otonominin kişisel ve mesleki güç algısı ile ilişkili kavramlardan olduğu, hem güçlendiren hem de güçsüzleştiren tarafi olduğu belirtilmektedir (Abu-Bader, 2000; Aghove diğ., 1993; Arches, 1991; Oktay, 1992; Poulin, 1996; Poulin, 1994; Poulin ve Walter, 1992). Örneğin Kat1 ve bürokratik sınırlamaların sosyal hizmet uzmanlarının otonomilerini engellediği belirtilmektedir (Lawler ve Hage, 1973). Acar ve diğerleri (2017) tarafından 59 kişi ile yapılan nitel araştırmada siyasî baskının hizmetin hemen hemen her aşamasında meslek elemanları üzerinde kendisini hissettirdiği ve bu nedenle profesyonel özerkliğin kaybına neden olduğu sonucuna ulaşılmıştır. İsrail'de 218 sosyal hizmet uzmanı ile yapılan çalışmada iş yerinde daha yüksek otonominin daha yükssek doyumla ilişkili olduğu, iş doyumu ve tükenmişliğin otonomi düzeyinden etkilendiği sonucuna ulaşılmıştır (Abu-Bader, 2000). Yine Massachusetts kentinde çalışmakta olan 275 sosyal hizmet uzmanı ile yapılan araştırmada otonomiden yoksun olmak tükenmişliğin temel bileşeni olarak gösterilirken diğer taraftan algılanan otonominin iş doyumunun temel bileşenlerinden olduğu belirtilmektedir (Arches, 1991). AIDS hastaları ile çalışan 128 tıbbi sosyal hizmet uzmanı ile yapılan araştırmada da benzer sonuçlar elde edilmiştir (Oktay, 1992). Kaliforniya eyaletine kayıtlı 1500 sosyal hizmet uzmanından 346'sı ile yapılan kesitsel çalışmada işteki otonominin işten ayrılma niyeti üzerinde doğrudan ve negatif bir etkisi olduğu sonucuna ulaşılmıştır (Kim ve Stoner, 2008). Evans ve diğerleri (2006) tarafından ruh sağlığı alanında çalışan 610 sosyal hizmet uzmanı ile yapılan araştırmada ise otonomiye sahip olamamanın stresin önemli bir bileşeni olduğu ortaya koyulmuştur. 


\subsection{Terfi İmkânı}

Terfi imkânının diğer bir ifade ile ilerleme veyahut yükselme imkânının hem özel hem de devlet sektöründeki motivasyonel etmenler arasında ilk sıralarda yer aldığı (Jurkiewicz ve diğ., 1998; Stroh ve diğ., 1996), ayrıca terfi imkânın bir işin "iyi" kategorisinde yer almasını sağladığı (Jurgensen, 1978) belirtilmektedir. Ayrıca söz konusu imkânın işteki performansı arttırdığı ifade edilmektedir (Hogan ve diğ., 1998). Buna karşın terfi imkânının olmamasının güçsüzleştiren bir etmen olduğu literatürde vurgulanmaktadır (Gellis, 2001; Pugh, 2007; Smerek ve Peterson, 2007). Örneğin hastanelerde görevli 187 sosyal hizmet uzmanı ile yapılan araştırmada uzmanların terfi imkânlarından yoksun olmasının başat stres faktörlerinden biri olduğu bulgulanmıştır (Gellis, 2001). Pugh (2007) da terfi veyahut ilerleme imkânlarının olmamasının sosyal hizmet uzmanları üzerinde stres ve baskı oluşturduğunu desteklemektedir. Ayrıca iş doyum puanlarını anlamlı bir şekilde düşürdüğü de tespit edilmiştir (Smerek ve Peterson, 2007). Bunun dışında ilerleme imkânı önündeki engellerin işten ayrılma ile ilişkili olabileceği belirtilmektedir (Johari, 2013).

\section{SONUÇ ve ÖNERILER}

Hem yurt içi (Tuncay, 2009; Akın, 2018; Karabudak, 2016; Baltac1, 2016; Dağ, 2017; Atatanır, 2016; Görgülü, 2016; Tekindal, 2015; Özgişi, 2012; Kurnaz-Özdemir, 2010; Çamur-Duyan, 2006; CankurtaranÖntaş, 2004; Buz, 2012) hem de yurt dış1 (Early, 2001; Early ve GlenMaye, 2000; Laursen, 2000; Black, 2003; Gutierrez, 1990; Chapin ve Cox, 2002; Fast ve Chapin, 1995; Sullivan ve Fisher, 1994; Chazinve diğ., 2000; Chapin, 1995; Weick ve Saleebey, 1995; Clark, 1998; Clark, 2000; Maruna ve LeBel, 2002; Okundayeve diğ., 2001; Barry ve diğ., 2003; Björkman ve diğ., 2002; Cox, 2006; Deegan, 1997; Link ve diğ., 1989; McGovern, 2015; Rapp ve Chamberlain, 1985; Rapp ve Goscha, 2011; Rapp ve Wintersteen, 1989; Abdullah, 2015; Graham ve diğ., 2009; Benard, 2006; Singh ve diğ., 1995; Rogers ve diğ., 2010; Matthews ve diğ., 2003; Koren ve diğ., 1992; Nanda, 2011) sosyal hizmet literatüründe "güç ve güçlendirme" konuları genel itibari ile sosyal hizmet uzmanlarının hizmet vermekte oldukları müracaatçılar perspektifinden değerlendirilmektedir. Ancak diğer taraftan ihmal ve istismar mağdurları, madde bağımlıları, yoksulluk sınırının altında yaşayanlar, yaşlılar, engelliler, şiddet mağduru kadınlar vb. müracaatçı grupları ile sosyal hizmet uygulaması yapmak zorunda olan sosyal hizmet uzmanlarının güçlü yönlerinin neler olduğu ve hangi alanlarda güçlendirilmesi gerektiği hususu çoğu zaman gözden kaçırılmaktadır. Bu çalışmada da güçlendirmede çevresel faktörlerin öneminden hareketle iş yerinde güçlerin (Dee ve diğ., 2003; Speer ve Peterson, 2000; Spreitzer ve diğ., 1997; Thomas ve Velthouse, 1990; Zimmerman, 1990, 1995) neler olabileceğine dair bir literatür taraması sunulmuştur. Bu noktada hem bireysel düzlem hem de çevresel faktörler altında ele alınan işyerindeki güçler konusu harmanlanmaya çalışılmıştır. Elde edilen bilgiler ışığında öneriler aşağı

1. Güvencesiz (taşeron, ek ders karşılığı vb) çalışmanın bir insan hakkı ihlali olduğundan hareketle özelde sosyal hizmet alanında genelde ise tüm iş kollarından kaldırılması önerilebilir.

2. Mesleği isteyerek seçmenin önemi düşünülerek meslek seçimi konusunda yurt dişındaki uygulamalar örnek alınmalı ve çok erken yaşlarda yetenek tespiti yapılarak mesleki yönlendirme işlemleri yapılması önem arz etmektedir.

3. Başka bir kuruma geçmek isteyen veya işi bırakmak isteyen uzmanların nedenleri araştırılmalı ve bunlara ilişkin gerekli iyileştirmeler yapılmalıdır.

4. Sosyal hizmet kurumları içerisinde formal ve informal destek ve öneri mekanizmaların sağlanması konusunda herkesi bağlayıcı yapısal adımların atılması hem sosyal hizmet uzmanları hem de hizmet verdikleri müracaatçıların iyilik hali için önemli görülmektedir.

5. Her ne kadar müracaatçılar ile yapılan görüşmelerin ve diğer işlerin uzmanları güçlendirici bir etkisi olmasına rağmen uzmanların çalışma yoğunluğu azaltılarak daha nitelikli uygulamaların yapılmasının önü açılmalıdır.

6. Çalışma ortamı, sosyal hizmet uzmanların etik ilke ve değerlerine uygun olacak şekilde düzenlenmelidir.

7. Katı, hantal yönetim tarzları yerine sosyal hizmet uzmanlarının otonomilerine izin verecek şekilde uygulama yapmasının önündeki engellerin kaldırılması gerekmektedir.

8. Her çalışanın ilerleme imkânına sahip olması gerektiğinden hareketle şeffaf, ulaşılabilir ve ölçülebilir kriterler koyularak sosyal hizmet uzmanlarının terfi alması sağlanmalıdır.

9. Sosyal hizmet kurumlarındaki yöneticilerin sosyal hizmet alanına hâkim, uygulama deneyimi olan, insan ilişkilerinde iyi ve yapıcı olanlar arasından seçilmesi ve körleşmeye karşı yöneticilik görevinin çok uzun yıllar sürmesinden ziyade daha sınırlı bir zaman aralığında yapılması önerilmektedir. 


\section{KAYNAKÇA}

AASW. (2010). Australian Association of Social Workers Code of Ethics. Kingston: Australian Association of Social Workers.

Abdullah, S. (2015). An islamic perspective for strengths-based social work with muslim clients. Journal of Social Work Practice, 29(2), 163-172.

Abu-Bader, S. H. (2000). Work satisfaction, burnout, and turnover among social workers in Israel: A causal diagram. International Journal of Social Welfare, 9(3), 191-200.

Acar, H., İçağasığlu-Çoban, A., Polat, G. (2017). Sosyal hizmetlerde yanlış uygulamalar, etik ihlaller ve sorunlara ilişkin bir araştırma. Ankara: Türkiye Felsefe Kurumu Derneği.

Adams, R. (2003). Social Work and Empowerment. New York: Palgrave Macmillan.

Adams, R. (2008). Empowerment, participation and social work: Palgrave Macmillan.

Agho, A. O., Mueller, C. W., Price, J. L. (1993). Determinants of employee job satisfaction: An empirical test of a causal model. Human relations, 46(8), 1007-1027.

Akın, E. (2018). Adsız alkoliklerin ayıklık sürecine ilişskin anlatılarının güçlendirme temelinde değerlendirilmesi. (Yüksek Lisans Tezi), Hacettepe Üniversitesi Sosyal Bilimler Enstitüsü Sosyal Hizmetler Anabilim Dalı, Ankara.

Aktuğ, İ. Y., Susur, A., Keskin, S., Balcı, Y., Seber, G. (2006). Osmangazi Üniversitesi Tıp Fakültesinde çalışan hekimlerde tükenmişlik düzeyleri. Osmangazi Tıp Dergisi, 28(2), 91-101.

Amir, K., Kihoro, M. F. (2014). Work Stress And Coping Strategies Among Social Workers: A Case of Northern Ugand. International Journal of Liberal Arts and Social Science, 2(8), 33-38.

Arches, J. (1991). Social structure, burnout, and job satisfaction. Social Work, 36(3), 202-206.

Ardıç, K., Polatcı, S. (2008). Tükenmişlik sendromu akademisyenler üzerinde bir uygulama (GOÜ Örneği). İktisadi ve İdari Bilimler Fakültesi Dergisi, 10(2), 1-28.

Aslan, H., Aslan, R., Kesepara, C., Alparslan, N., Ünal, M. (1997). Kocaeli’nde bir grup sağlık çalışanında işe bağlı gerginlik, tükenme ve iş doyumu. Toplum ve Hekim, 12(82), 24-29.

Atatanır, H. (2016). Türkiye'de yoksulluk, sosyal yardım ve sivil toplum: Hak temelli yaklaşım açısından bir değerlendirme. (Doktora Tezi), Hacettepe Üniversitesi Sosyal Bilimler Enstitüsü Sosyal Hizmetler Anabilim Dal1, Ankara.

Aydemir, İ. (2003). Sağlık Bakanlığı'na bağlı hastanelerde tıbbi sosyal hizmet uygulamaları. (Yayınlanmamış Yüksek Lisans Tezi, ), Hacettepe Üniversitesi, Sosyal Bilimler Enstitüsü, Ankara.

Bakan, H., Tombak, N. (2014). İdari personelin tükenmişlik düzeylerinin sosyo-demografik değişkenler açısından incelenmesi: Muğla Sitk1 Koçman Üniversitesi Örneği. Journal of International Social Research, 7(35), 681-695.

Balanuye, B. (2014). Cerrahi kliniklerde çalışan hemşirelerin iş yükünün hasta güvenliğine etkisi. (Yüksek Lisans Tezi), Başkent Üniversitesi Sağlık Bilimleri Enstitüsü, Ankara.

Baltacı, G. (2016). Kadın dostu kentler projesinin freirean yaklaşım ve makro feminist sosyal hizmet uygulamaları üzerinden incelenmesi. (Doktora Tezi), Hacettepe Üniversitesi Sosyal Bilimler Enstitüsü Sosyal Hizmetler Anabilim Dalı, Ankara.

Barker, R. L. (1995). The Social Work Dictionary. Washington, DC: National Association of Social Workers.

Barry, K. L., Zeber, J. E., Blow, F. C., Valenstein, M. (2003). Effect of strengths model versus assertive community treatment model on participant outcomes and utilization: two-year follow-up. Psychiatric Rehabilitation Journal, 26(3), 268-277.

Basım, H., Şeşen, H. (2005). Çalışma yaşamında tükenmişlik: Sosyal hizmet uzmanları ile hemşireler üzerine karşılaştırmalı bir çalışma. Toplum ve Sosyal Hizmet, 16(2), 57-70.

Benach, J., Muntaner, C. (2007). Precarious employment and health: developing a research agenda. Journal of Epidemiology \& Community Health, 61(4), 276-277.

Benard, B. (2006). Using strengths-based practice to tap the resilience of families. In D. Saleebey (Ed.), The strengths perspective in social work practice (pp. 197-220). Boston, MA Allyn and Bacon.

Ben-Zur, H., Michael, K. (2007). Burnout, social support, and coping at work among social workers, psychologists, and nurses: The role of challenge/control appraisals. Social Work in Health Care, 45(4), 63-82.

Berkün, S. (2010). Sosyal Hizmet Uzmanlarının Çalışma Hayatında Karşılaştıkları Mesleki Sorunlar: Bursa Örneği. Toplum ve Sosyal Hizmet Dergisi, 21(1), 99-109.

Björkman, T., Hansson, L., Sandlund, M. (2002). Outcome of case management based on the strengths model compared to standard care. A randomised controlled trial. Social Psychiatry and Psychiatric Epidemiology, 37(4), 147-152.

Black, A. E., Deci, E. L. (2000). The effects of instructors' autonomy support and students' autonomous motivation on learning organic chemistry: A self-determination theory perspective. Science education, 84(6), 740-756.

Black, C. J. (2003). Translating principles into practice: Implementing the feminist and strengths perspectives in work with battered women. Affilia, 18(3), 332-349.

Blomberg, H., Kallio, J., Kroll, C., Saarinen, A. (2014). Job stress among social workers: Determinants and attitude effects in the Nordic countries. The British Journal of Social Work, 45(7), 2089-2105.

Brashears, F. (1995). Supervision as social work practice: A reconceptualization. Social Work, 40(5), 692-699.

Bujdová, N., Kmec, J. (2012). Supervision in Social Work. Clinical Social Work, 3, 83-87.

Butler, B. B. (1990). Job satisfaction: Management's continuing challenge. Social Work, 35(2), 112-117. 
Buz, S. (2012). Türkiye'deki sığınmacıların üçüncü bir ülkeye gidiş için bekleme sürecinde karşılaştıkları sorunlar. (Yüksek Lisans Tezi), Hacettepe Üniversitesi Sosyal Bilimler Enstitüsü Sosyal Hizmetler Anabilim Dalı, Ankara.

Calitz, T., Roux, A., Strydom, H. (2014). Factors that affect social workers' job satisfaction, stress and burnout. Social Work, 50(2), 153-169.

Çamur-Duyan, G. (2006). Sosyal Hizmet Bakış Açısından Yoksul Kadınlar: Altındağ Örneği.(Basılmamış Doktora Tezi). (Doktora Tezi), Hacettepe Üniversitesi Sosyal Bilimler Enstitüsü Sosyal Hizmetler Anabilim Dalı, Ankara.

Cankurtaran-Öntaş, Ö. (2004). Çocuk Hakları ve Sosyal Hizmetin Güçlendirme Yaklaşımı Açısından Suça Yönelen Çocuk-Polis İlişkisi. (Doktora Tezi), Hacettepe Üniversitesi Sosyal Bilimler Enstitüsü Sosyal Hizmetler Anabilim Dalı, Ankara.

Carpenter, J., Webb, C., Bostock, L., Coomber, C. (2017). Effective Supervision in Social Work and Social Care. Research Briefing 43. London: Social Care Institute for Excellence.

Çetin, E., Avşar, M. K., Temelli, M. E. (2015). Sosyal Hizmet Kurumlarında "Sosyal Hizmetsiz Yönetim" ve Sosyal Hizmet Uzmanlarının Karşılaştı̆̆ Zorluklar; ASPB Örneği. Paper presented at the Sosyal Hizmet Sempozyumu 2015 Türkiye'de Sosyal Hizmet Uygulamasının 50. Y1lı: İnsan Değer ve Onurunu Yüceltmek, Manisa.

Ceylan, H., Gül, N., Öksüz, M. (2016). Sosyal Çalışmacılarda İş Doyumu ve Tükenmişliğe Etki Eden Faktörlerin Sosyal Hizmet Alanlarına Göre Karşılaştırmalı İncelenmesi1. Yalova Sosyal Bilimler Dergisi, 6(11), 43-69.

Chandler, G. E. (1987). The relationship of nursing work environment to empowerment and powerlessness. Dissertation Abstracts International, 47(12), 4822-B.

Chapin, R. K. (1995). Social policy development: The strengths perspective. Social Work, 40(4), 506-514.

Chapin, R., Cox, E. O. (2002). Changing the paradigm: Strengths-based and empowerment-oriented social work with frail elders. Journal of Gerontological Social Work, 36(3-4), 165-179.

Chazin, R., Kaplan, S., Terio, S. (2000). The strengths perspective in brief treatment with culturally diverse clients. Crisis Intervention, 6(1), 41-50.

Cherniss, C. (1980). Staff burnout: Job stress in the human services: Sage Publications Beverly Hills, CA.

Clark, M. D. (1998). Strength-Based Practice-The ABC's of Working with Adolescents Who Don't Want to Work with You. Fed. Probation, 62, 46.

Clark, M. D. (2000). Influencing Postive Behavior Change: Increasing the Therapeutic Approach of Juvenile Courts. Fed. Probation, 65(1), 18.

Clarke, M., Lewchuk, W., de Wolff, A., King, A. (2007). 'This just isn't sustainable': Precarious employment, stress and workers' health. International Journal of Law and Psychiatry, 30(4-5), 311-326.

Coffey, M., Dugdill, L., Tattersall, A. (2004). Stress in social services: Mental wellbeing, constraints and job satisfaction. British Journal of Social Work, 34(5), 735-746.

Collings, J. A., Murray, P. J. (1996). Predictors of stress amongst social workers: An empirical study. The British Journal of Social Work, 26(3), 375-387.

Collins, S. (2007). Statutory social workers: Stress, job satisfaction, coping, social support and individual differences. British Journal of Social Work, 38(6), 1173-1193.

Cooper, C. (1981). Reviewed Work: Staff Burnout: Job Stress in the Human Services by Cary Cherniss. The British Journal of Social Work, 11(4), 506-508.

Cox, K. F. (2006). Investigating the impact of strength-based assessment on youth with emotional or behavioral disorders. Journal of Child and Family Studies, 15(3), 278-292.

Dağ, A. (2017). Lise öğrencilerinin arkadaş-akran gruplarından dişlanmasının okul sosyal hizmeti açısından analizi: Sakarya örneği. (Doktora Tezi), Yalova Üniversitesi Sosyal Bilimler Enstitüsü Sosyal Hizmetler Anabilim Dalı Sosyal Hizmet Bilim Dalı, Yalova.

Dee, J. R., Henkin, A. B., Duemer, L. (2003). Structural antecedents and psychological correlates of teacher empowerment. Journal of educational Administration, 41(3), 257-277.

Deegan, P. E. (1997). Recovery and empowerment for people with psychiatric disabilities. Social Work in Health Care, 25(3), 11-24.

Dolunay, A. B. (2002). Keçiören İlçesi" Genel liseler ve Teknik-Ticaret-Meslek Liselerinde Görevli Öğretmenlerde Tükenmişlik Durumu" Araştırması. Ankara Üniversitesi Tıp Fakültesi Mecmuası, 55(1), 51-62.

Dominelli, L. (2002). Anti oppressive social work theory and practice. London: Palgrave Macmillan.

Dominelli, L. (2010). Globalization, contemporary challenges and social work practice. International Social Work, 53(5), 599-612.

Dominelli, L. (2015). Sosyal Hizmeti Yeniden Konumlandirmak. In R. Adams, L. Dominelli, M. Payne (Eds.), Sosyal Hizmet Temel Alanlar ve Eleştirel Yaklaşımlar (pp. 45-57). Ankara: Nika Yayınevi.

Dominelli, L. (2017). Anti-racist social work. London: Palgrave Macmillan.

Early, T. (2001). Measures for practice with families from a strengths perspective. Families in Society: The Journal of Contemporary Social Services, 82(3), 225-232.

Early, T. J., GlenMaye, L. F. (2000). Valuing Families: Social Work Practice with Families From a Strengths Perspective. Social Work, 45(2), 118-130.

Eğinli, A. T. (2009). Çalışanlarda İş Doyumu: Kamu ve Özel Sektör Çalışanlarının İş Doyumuna Yönelik Bir Araştırma. Atatürk Üniversitesi İktisadi ve İdari Bilimler Dergisi, 23(3), 35-52. 
Evans, S., Huxley, P., Gately, C., Webber, M., Mears, A., Pajak, S., . . Katona, C. (2006). Mental health, burnout and job satisfaction among mental health social workers in England and Wales. The British Journal of Psychiatry, 188(1), 75-80.

Fast, B., Chapin, R. (1995). The strengths model in long-term care: linking cost containment and consumer empowerment. Journal of case management, 5(2), 51-57.

Frans, D. J. (1993). A scale for measuring social worker empowerment. Research on Social Work Practice, 3(3), $312-$ 328.

French, J. R., Raven, B., Cartwright, D. (1959). The bases of social power. Classics of organization theory, 7, $311-320$.

Gellis, Z. D. (2001). Job stress among academic health center and community hospital social workers. Administration in Social Work, 25(3), 17-33.

Görgülü, T. (2016). Denetimli serbestlik uygulamalarından yararlanan bireylerin psikososyal özelliklerinin intihar davranışına etkileri. (Doktora Tezi), Hacettepe Üniversitesi Sosyal Bilimler Enstitüsü Sosyal Hizmetler Anabilim Dalı, Ankara.

Graham, J. R., Bradshaw, C., Trew, J. L. (2009). Adapting social work in working with Muslim clients. Social Work Education, 28(5), 544-561.

Gutierrez, L. M. (1990). Working with women of color: An empowerment perspective. Social Work, 35(2), $149-153$.

Güzel, B., Selcik, O. (2017b). Sosyal çalışmacıların karşılaştıkları zorluklar ve başa çıkma yolları: Rize örneği. Uluslararası İnsan Bilimleri Dergisi, 14(3), 2848-2864.

Hablemitoğlu, Ş., Özmete, E. (2012). Sosyal Çalışmacıların İş Yaşamı Kalitesi, Şefkat Yorgunluğu, Tükenmişlik, Stres Kaynakları, İş Tatmini ve Kariyer Olanakları. Ankara Sağlık Bilimleri Dergisi, 1(1), 171-204.

Hasenfeld, Y. (1987). Power in social work practice. Social service review, 61(3), 469-483.

Hogan, J., Rybicki, S. L., Borman, W. C. (1998). Relations between contextual performance, personality, and occupational advancement. Human Performance, 11(2-3), 189-207.

Holland, J. L. (1997). Making vocational choices: A theory of vocational personalities and work environments. Odessa, FL, US: Psychological Assessment Resources.

İçağasıoğlu-Çoban, M. A., Özbesler, C. (2016). Hastanelerde Çalışan Sosyal Hizmet Uzmanlarında Tükenmişlik ve İş Doyumu. Başkent Üniversitesi Sağlık Bilimleri Fakültesi Dergisi-BÜSBİD, 1(2), 90-109.

IFSW. (2012). Effective and ethical working environments for social work: the responsibilities of employers of social workers. Berne: International Federation of Social Workers.

Işıkhan, V. (1999). Sosyal Hizmet Ve Sağlik Alaninda Görev Yapan Yöneticileri Etkileyen İş Stres Faktörleri. Amme İdaresi Dergisi (TODAİ), 32(2), 43-57.

Işıkhan, V. (2010). Sosyal Hizmet ve Tükenmişlik. Ankara: Vizyon Kırtasiye-Ofset Matbaa-Yayınevi.

Işıkhan, V. (2011). Sosyal hizmet ve tükenmişlikle başa çıkma. Ankara: Vizyon Ofset ve Matbaa.

Jex, S. M., Britt, T. W. (2014). Organizational psychology: A scientist-practitioner approach: John Wiley \& Sons.

Johari, J. (2013). A proposed relationship between actual turnover behaviour, career advancement opportunity, frustration at work and perceived alternative job opportunities among faculty members. Am J Econ, 3(5C), 82e86.

Johnson, S., Cooper, C., Cartwright, S., Donald, I., Taylor, P., Millet, C. (2005). The experience of work-related stress across occupations. Journal of managerial psychology, 20(2), 178-187.

Jones, C. (2001). Voices from the front line: state social workers and New Labour. British Journal of Social Work, 31(4), 547-562.

Jones, D. N., Truell, R. (2012). The Global Agenda for Social Work and Social Development: A place to link together and be effective in a globalized world. International Social Work, 55(4), 454-472.

Jurgensen, C. E. (1978). Job preferences (What makes a job good or bad?). Journal of Applied psychology, 63(3), 267.

Jurkiewicz, C. L., Massey Jr, T. K., Brown, R. G. (1998). Motivation in public and private organizations: A comparative study. Public productivity \& Management review, 230-250.

Kadushin, A., Harkness, D. (2014). Supervision in social work. New York: Columbia University Press.

Kadushin, A., Kadushin, G. (2016). Sosyal Hizmette Görüşme Teknikleri. Ankara: Nika Yayınevi.

Kalayc1-Kırlığlu, H. İ., Kırlığlu, M., Ercan, F. Z. (2017). A Subcontractor of a Profession Whose Main Purpose is to Provide Social Justice and Prevent from Loss of Rights: Social Workers Sample. Paper presented at the III.International Balkan and Near Eastern Social Sciences Congress Series, Edirne.

Kalleberg, A. L. (2009). Precarious work, insecure workers: Employment relations in transition. American sociological review, 74(1), 1-22.

Kalliath, P., Kalliath, T. (2013). Work-family conflict and its impact on job satisfaction of social workers. British Journal of Social Work, 45(1), 241-259.

Kamaşak, R., Bulutlar, F. (2010). Kişilik, mesleki tercih ve performans ilişkisi: akademik personel üzerine bir araştırma. Organizasyon ve Yönetim Bilimleri Dergisi, 2(2), 119-126.

Kaplanoglu, E. (2014). Mesleki Stresin Temel Nedenleri Ve Muhtemel Sonuçlari: Manisa Ilindeki SMMM'ler Üzerine Bir Arastirma. Muhasebe ve Finansman Dergisi(64), 131-150.

Karabudak, G. (2016). Lösemili çocuğa sahip annelerin yaşantıları ve gelecek beklentileri. (Yüksek Lisans Tezi), Hacettepe Üniversitesi Sosyal Bilimler Enstitüsü Sosyal Hizmetler Anabilim Dalı, Ankara.

Karacaoğlu, K., Çetin, İ. (2015). İş Yükü ve Rol Belirsizliğinin Çalışanların Tükenmişlik Düzeylerine Etkisi. Nevşehir Hacı Bektaş Veli Üniversitesi İktisadi ve İdari Bilimler Fakültesi, 5(1), 46-69. 
Kim, H., Stoner, M. (2008). Burnout and turnover intention among social workers: Effects of role stress, job autonomy and social support. Administration in Social Work, 32(3), 5-25.

Kim, I. H., Khang, Y. H., Muntaner, C., Chun, H., Cho, S. I. (2008). Gender, precarious work, and chronic diseases in South Korea. American journal of industrial medicine, 51(10), 748-757.

Kim, M.-H., Kim, C.-y., Park, J.-K., Kawachi, I. (2008). Is precarious employment damaging to self-rated health? Results of propensity score matching methods, using longitudinal data in South Korea. Social Science \& Medicine, 67(12), 1982-1994.

Kırlığlu, M., Karakuş, Ö. (2019). Sosyal hizmet uzmanlarının kişisel ve mesleki güç algıları ölçeğinin geçerlilik ve güvenirlik çalışması. Toplum ve Sosyal Hizmet, 30(1), 88-120.

Koç, S. Ç. (2015). Sosyal Hizmet Uzmanlarının Sorun Çözme Becerileri Üzerine Bir Araştırma. (Yüksek Lisans Tezi), Hacettepe Üniversitesi Sosyal Bilimler Enstitüsü Ankara.

Kol, E. (2009). Türkiye'de sağlık işletmelerinde sosyal hizmet uygulamaları. (Yayınlanmamış yüksek lisans tezi), Anadolu Üniversitesi Sosyal Bilimler Enstitüsü, Eskişehir.

Koren, P. E., DeChillo, N., Friesen, B. J. (1992). Measuring empowerment in families whose children have emotional disabilities: A brief questionnaire. Rehabilitation Psychology, 37(4), p305-321.

Kurnaz-Özdemir, D. (2010). Ortopedik Engelli Kadınların Sorun ve Beklentileri: Tuzla İlçesi Örneği. (Yüksek Lisans Tezi), Hacettepe Üniversitesi Sosyal Bilimler Enstitüsü Sosyal Hizmetler Anabilim Dalı, Ankara.

Kuzgun, Y. (2006). Meslek gelişimi ve danışmanlığı (4. Baskı). Nobel Yayınları, Ankara.

Laursen, E. K. (2000). Strength-based practice with children in trouble. Reclaiming Children and Youth, 9(2), 70-75.

Lawler, E. J., Hage, J. (1973). Professional-bureaucratic conflict and intraorganizational powerlessness among social workers. J. Soc. \& Soc. Welfare, 1, clxxiv.

Lewchuk, W., De Wolff, A., King, A., Polanyi, M. (2003). From job strain to employment strain: Health effects of precarious employment. Just Labour.

Link, B. G., Cullen, F. T., Struening, E., Shrout, P. E., Dohrenwend, B. P. (1989). A modified labeling theory approach to mental disorders: An empirical assessment. American sociological review, 54(3), 400-423.

Lloyd, C., King, R. (2004). A survey of burnout among Australian mental health occupational therapists and social workers. Social Psychiatry and Psychiatric Epidemiology, 39(9), 752-757.

Lloyd, C., King, R., Chenoweth, L. (2002). Social work, stress and burnout: A review. Journal of mental health, 11(3), $255-265$

Lloyd, C., McKenna, K., King, R. (2005). Sources of stress experienced by occupational therapists and social workers in mental health settings. Occupational therapy international, 12(2), 81-94.

Lymbery, M. (1998). Care management and professional autonomy: The impact of community care legislation on social work with older people. The British Journal of Social Work, 28(6), 863-878.

Maruna, S., LeBel, T. P. (2002). Welcome Home-Examinging the Reentry Court Concept from a Strengths-Based Perspective. W. Criminology Rev., 4, 91-107.

Matthews, R. A., Michelle Diaz, W., Cole, S. G. (2003). The organizational empowerment scale. Personnel Review, 32(3), 297-318.

McCloskey, J. C. (1990). Two requirements for job contentment: autonomy and social integration. Journal of Nursing Scholarship, 22(3), 140-143.

McGovern, J. (2015). Living better with dementia: strengths-based social work practice and dementia care. Social Work in Health Care, 54(5), 408-421.

Menéndez, M., Benach, J., Muntaner, C., Amable, M., O’Campo, P. (2007). Is precarious employment more damaging to women's health than men's? Social Science \& Medicine, 64(4), 776-781.

Merighi, J., Ehlebracht, K. (2005). Emotional exhaustion and workload demands in renal social work practice. Journal of Nephrology Social Work, 24, 14-20.

Miley, K. K., O'Melia, M. W., DuBois, B. L. (2016). Generalist social work practice: An empowering approach: Pearson.

Min, J. Y., Park, S. G., Hwang, S. H., Min, K. B. (2016). Disparities in precarious workers' health care access in South Korea. American journal of industrial medicine, 59(12), 1136-1144.

Mollaoğlu, M., Fertelli, T. K., Tuncay, F. Ö. (2010). Hastanede çalışan hemşirelerin çalışma ortamlarına ilişkin algılarının değerlendirilmesi. Firat Sağlık Hizmetleri Dergisi, 5(15), 17-30.

Munson, C. E. (1996). Autonomy and managed care in clinical social work practice. Smith College Studies in Social Work, 66(3), 241-260.

Nanda, G. (2011). Compendium of gender scales. Washington, DC: FHI, 360.

Niemiec, C. P., Ryan, R. M. (2009). Autonomy, competence, and relatedness in the classroom: Applying selfdetermination theory to educational practice. School Field, 7(2), 133-144.

Oktay, J. S. (1992). Burnout in hospital social workers who work with AIDS patients. Social Work, 37(5), $432-439$.

Okundaye, J. N., Smith, P., Lawrence-Webb, C. (2001). Incorporating spirituality and the strengths perspective into social work practice with addicted individuals. Journal of Social Work Practice in the Addictions, 1(1), 65-82.

Özarallı, N., Torun, A. (2011). Biçimsel ve biçimsel olmayan iletişim, yönetici ile kuruma duyulan güven ve üstün uzmanlık gücü arasındaki ilişkiler üzerine bir araştırma. Bilgi Ekonomisi ve Yönetimi Dergisi. VI (II), 101-113.

Özbesler, C., İçağasığlu-Çoban, M. A. (2009). Hastane ortamında sosyal hizmet ugyulamaları: Ankara Örneği. Toplum ve Sosyal Hizmet, 21(2), 31-45. 
Özcan, E., Özden, S. A., İçağasığlu-Çoban, A. (2017). Sosyal hizmet uzmanlarının güvencesiz çalışma biçimine ilişkin deneyimlerinin değerlendirilmesi. Journal of Human Sciences, 14(1), 376-395.

Özgişi, H. N. (2012). Yalova Belediyesi'nin kadın hizmetleri: Karanfil Evleri örneği. (Yüksek Lisans Tezi), Yalova Üniversitesi Sosyal Bilimler Enstitüsü Sosyal Hizmetler Anabilim Dalı, Yalova.

Parry-Jones, B., Grant, G., McGrath, M., Caldock, K., Ramcharan, P., Robinson, C. A. (1998). Stress and job satisfaction among social workers, community nurses and community psychiatric nurses: implications for the care management model. Health \& social care in the community, 6(4), 271-285.

Poulin, J. (1996). Job satisfaction of social work supervisors and administrators. Administration in Social Work, 19(4), $35-49$.

Poulin, J. E. (1994). Job task and organizational predictors of social worker job satisfaction change: A panel study. Administration in Social Work, 18(1), 21-38.

Poulin, J. E., Walter, C. A. (1992). Retention plans and job satisfaction of gerontological social workers. Journal of Gerontological Social Work, 19(1), 99-114.

Powell, M. B., Guadagno, B. L., Cassematis, P. (2013). Workplace stressors for investigative interviewers of child-abuse victims. Policing: an international journal of police strategies \& management, 36(3), 512-525.

Pugh, R. (2007). Dual relationships: Professional and personal boundaries in rural communities. British Journal of Social Work, 37, 1405-1423.

Rapp, C. A., Chamberlain, R. (1985). Case management services for the chronically mentally ill. Social Work, 30(5), 417-422.

Rapp, C. A., Goscha, R. J. (2011). The strengths model: A recovery-oriented approach to mental health services. USA: OUP

Rapp, C. A., Wintersteen, R. (1989). The Strengths model of case management: Results from twelve demonstrations. Psychosocial Rehabilitation Journal, 13(1), 23.

Raven, B. H. (1993). The bases of power: Origins and recent developments. Journal of social issues, 49(4), $227-251$.

Robinson, K. (2013). Voices from the front line: Social work with refugees and asylum seekers in Australia and the UK. British Journal of Social Work, 44(6), 1602-1620.

Rogers, E. S., Ralph, R. O., \& Salzer, M. S. (2010). Validating the empowerment scale with a multisite sample of consumers of mental health services. Psychiatric Services, 61(9), 933-936.

Sayıl, I., Haran, S., Ölmez, Ş., Özgüven, H. D. (1997). Ankara Üniversitesi hastanelerinde çalışan doktor ve hemşirelerin tükenmişlik düzeyleri. Kriz dergisi, 5(2), 71-77.

Seifert, A. M., Messing, K., Riel, J., Chatigny, C. (2007). Precarious employment conditions affect work content in education and social work: Results of work analyses. International journal of law and psychiatry, 30(4), 299-310.

Sheafor, B., Horejsi, C. (2014). Sosyal Hizmet Uygulaması Temel Teknikler ve İlkeler. Ankara: Nika Yayınevi.

Siefert, K., Jayaratne, S., Chess, W. A. (1991). Job satisfaction, burnout, and turnover in health care social workers. Health \& Social Work, 16(3), 193-202.

Singh, N. N., Curtis, W. J., Ellis, C. R., Nicholson, M. W., Villani, T. M., Wechsler, H. A. (1995). Psychometric analysis of the family empowerment scale. Journal of Emotional and Behavioral Disorders, 3(2), 85-91.

Smerek, R. E., Peterson, M. (2007). Examining Herzberg's theory: Improving job satisfaction among non-academic employees at a university. Research in Higher Education, 48(2), 229-250.

Speer, P. W., Peterson, N. A. (2000). Psychometric properties of an empowerment scale: Testing cognitive, emotional, and behavioral domains. Social Work Research, 24(2), 109-118.

Spolander, G., Engelbrecht, L., Martin, L., Strydom, M., Pervova, I., Marjanen, P., . . . Adaikalam, F. (2014). The implications of neoliberalism for social work: Reflections from a six-country international research collaboration. International Social Work, 57(4), 301-312.

Spreitzer, G. M. (1995). Psychological empowerment in the workplace: Dimensions, measurement, and validation. Academy of management Journal, 38(5), 1442-1465.

Spreitzer, G. M., Kizilos, M. A., Nason, S. W. (1997). A dimensional analysis of the relationship between psychological empowerment and effectiveness satisfaction, and strain. Journal of management, 23(5), 679-704.

Staudt, M. (1985). The social worker as an advocate in adult protective services. Social Work, 30(3), 204-208.

Storey, J., Billingham, J. (2001). Occupational stress and social work. Social Work Education, 20(6), 659-670.

Stroh, L. K., Brett, J. M., Reilly, A. H. (1996). Family structure, glass ceiling, and traditional explanations for the differential rate of turnover of female and male managers. Journal of Vocational Behavior, 49(1), 99-118.

Sullivan, W. P., Fisher, B. J. (1994). Intervening for success: Strengths-based case management and successful aging. Journal of Gerontological Social Work, 22(1-2), 61-74.

Super, D. E. (1951). Vocational adjustment. Journal of Counseling \& Development, 30(2), 88-92.

TDK. (2018). Güncel Türkçe Sözlük. Ankara: T.C. Başbakanlık Atatürk Kültür, Dil ve Tarih Yüksek Kurumu.

Teater, B. (2015). Sosyal Hizmet Kuram ve Yöntemleri (A. Karatay, Trans.). Ankara: Nika Yayınevi.

Tekindal, M. (2015). Engelli çocuğa sahip kadınların feminist grup çalışması deneyimi: Bir karma yöntem araştırması. (Doktora Tezi), Hacettepe Üniversitesi Sosyal Bilimler Enstitüsü Sosyal Hizmetler Anabilim Dalı, Ankara.

Thomas, K. W., Velthouse, B. A. (1990). Cognitive elements of empowerment: An "interpretive" model of intrinsic task motivation. Academy of management review, 15(4), 666-681.

Thompson, N. (2013). Kuram ve Uygulamada Sosyal Hizmeti Anlamak. Ankara Dipnot Yayınları. 
Thompson, N. (2016). Güç ve Güçlendirme. Ankara: Nika Yayınevi.

Tomanbay, İ. (2011). Sosyal hizmetlerde açık öğretim ve ara elemanlar: Sosyal çalışma ve sosyal teknikerlik. Ankara: SABEV.

Tuncay, T. (2009). Genç kanser hastalarının hastalık anlatılarının güçlendirme yaklaşımı temelinde analizi. Toplum ve Sosyal Hizmet Dergisi, 20(2), 69-87.

Uğur, A., Erol, Z. (2015). Sosyal çalışmacıların çalışma hayatında karşılaştıkları stres faktörlerine yönelik kavramsal bir değerlendirme ve stres yönetimi müdahale programları. Uluslararası Sosyal Araştırmalar Dergisi, 8(39), 987-997.

Uz, O. (2006). T. C. Kamu sektöründe yönetici-yönetilen ilişsilerinde iletişim ve güven. Atılım Üniversitesi Sosyal Bilimler Enstitüsü İşletme Yönetimi Anabilim Dalı, Ankara.

Wagner, R., Van Reyk, P., Spence, N. (2001). Improving the working environment for workers in children's welfare agencies. Child and Family Social Work, 6(2), 161-178.

Weick, A., Saleebey, D. (1995). Supporting family strenghts: Orienting policy and practice toward the 21 st century. Families in Society, 76(3), 141-149.

Whitaker, T., Weismiller, T., Clark, E., Wilson, M. (2006). Assuring the sufficiency of a frontline workforce: A national study of licensed social workers-Special Report: Social Work Services for Children and Families. Washington, DC: National Association of Social Workers.

William, J. R. (1998). The Paradigms and Long-Term Trends in Clinical Social Work. In R. A. Dorfman (Ed.), Paradims of Clinical Social Work (pp. 339-340). New York: Brunner-Routledge.

Yağcı, C. (2017). Aile ve sosyal politikalar bakanlığı'na bağlı çocuk refahı kurumlarında çalışan sosyal hizmet uzmanlarının iş yükleri ve tükenmişlik düzeyleri. (Yayınlanmamış Yüksek Lisans Tezi), Kocaeli Üniversitesi Sosyal Bilimler Enstitüsü, Kocaeli.

Yalçınkaya, M. (2007). Yöneticilerin iletişim becerilerinin çalışanların yaratıcılıklarının ortaya çıkarması, yöneticiye güven ve örgütte işbirliği ruhunun gelişmesine etkisinin incelenmesi: Kütahya porselen ve cam sektöründe bir uygulama. (Yayınlanmamış yüksek lisans tezi), Dumlupınar Üniversitesi Sosyal Bilimler Enstitüsü İşletme Anabilim Dalı Yönetim ve Organizasyon Bilim Dalı, Kütahya.

Yürür, S., Sarıkaya, M. (2012). The effects of workload, role ambiguity, and social support on burnout among social workers in Turkey. Administration in Social Work, 36(5), 457-478.

Zengin, O., Çalış, O. (2017). Sosyal Hizmet Uzmanlarının Mesleki Uygulamaları Ve Çalışma Koşulları. Toplum ve Sosyal Hizmet, 28(1), 47-68.

Zimmerman, M. A. (1990). Taking aim on empowerment research: On the distinction between individual and psychological conceptions. American Journal of community psychology, 18(1), 169-177.

Zimmerman, M. A. (1995). Psychological empowerment: Issues and illustrations. American Journal of community psychology, 23(5), 581-599. 